\title{
Öğrenme Stili Modelleri: Teorik Temelleri Bağlamında Kapsayıcı Bir Derleme Çalışması
}

\author{
DOI: 10.26466/opus.603506
}

$*$

\author{
Etem Yesilyurt * \\ * Doç. Dr., Akdeniz Üniversitesi, Eğitim Fakültesi, Konyaaltı / Antalya / Türkiye \\ E-Posta: etemyesilyurt@akdeniz.edu.tr \\ ORCID: 0000-0002-7340-7536 \\ $\ddot{O} z$
}

Öğretmen merkezli eğitimden öğrenci merkezli eğitime geçiş eğitim sistemini çok etkileyen değişimler arasında yer almaktadır. Bu değişim, içerisinde öğrenme stillerinin olduğu öğrenenlerin bireysel farklılıklarını öğrenme alanına daha fazla taşımaktadır. Genel ifadeyle, kişilik ve yetenek arasında bir bağlantı olan stil; bireyin yeteneklerini kullanmadaki tercihi, bilgi ve becerisini uygulamaya koyarken kullanmayı tercih ettiği yoldur. Ö̆̆grenme stili ise bir öğrencinin doğuştan getirdiği, bilgiyi öğrenirken, hatırlarken, uygularken kendine, özgü kullandı̆̆ı yol, nasıl öğrendiğini ve öğrenmekten hoşlandığını gösteren durum, öğrenme süreci ve koşullarındaki eğilimleri veya tercihleri şeklinde tanımlanabilir. Bireyin öğrenme stilleri, öğrenme açısından onun önemli bireysel farklılarından birisini oluşturmaktadır. Konu hakkında çalı̧̧an kimi yazarlara göre öğrenme stilinin belirlenmesi ve bilinmesi, bireyin kan grubunun belirlenmesi ve bilinmesi kadar önemli görülmekte, öğrenme stillerinin öğrenme açısından ne kadar büyük bir öneme sahip olduğu vurgulanmaktadır. Alanyazın taraması sonucunda erişilen kaynaklarda (kitaplar, tezler, makaleler, bildiriler) öğrenme stillerinin tamamının bir bütünlük içerisinde ve kapsaml olarak açıklamasına ulaşılamamıştır. Derleme niteliği taşıyan bu çalışma kapsamında öncelikle stil ve öğrenme stili kavramlarına yer verilmiştir. Öğrenme stillerinin genel özelliklerine değinildikten sonra alanyazında en fazla yer alan öğrenme stili modelleri ayrıntılı bir şekilde ele alınmış ve açıklanmıştır. Alanyazında farklı kaynaklarda yer alan öğrenme stillerinin bir bütünlük içerisinde ve tek çalışma kapsamında ele alınması çalışmanın özgünlüğü ortaya koymakta ve bu bakımdan alana katkı sağlayacağı umulmaktadır.

Anahtar Kelimeler: Öğrenme stilleri, öğrenmede bireysel farklılıklar, öğretim-öğrenme yöntem ve teknikleri. 


\title{
Learning Style Models: A Comprehensive Review in the Context of Theoretical Basics
}

\begin{abstract}
The transition from teacher-centered education to student-centered education is among the changes that affect education systems. This change makes the individual differences of the learners more important, including learning styles. In general terms, style is a link between talent and personality; the preference of the individual to use his / her abilities is the way he / she prefers to use his / her knowledge and skills. Learning style can be defined as the way in which a student is born, his / her own way of learning, remembering or using the information, the situation that shows how he / she learns and likes to learn, trends or preferences in the learning process and conditions. Learning styles of the individual constitute one of its important individual differences in terms of learning. According to some authors working on the subject, determining and knowing the learning style is considered as important as determining and knowing the blood type of the individual and emphasizing the importance of learning styles in terms of learning. As a result of literature review, it is not possible to provide a comprehensive explanation of all learning styles in the sources. In the context of this compilation study, firstly, the concepts of style and learning style are included. After mentioning the general characteristics of learning styles, the most common learning style models in the literature were discussed and explained in detail. Studying the learning styles in different sources within the context of a single study in the literature shows the originality of the study and it is hoped that this study will contribute to the field.
\end{abstract}

Keywords: Learning styles, individual differences in learning, learning-teaching methods and techniques 


\section{Giriş}

Öğretmen merkezli eğitimden öğrenci merkezli eğitime geçiş, eğitim sistemlerini en fazla etkileyen değişimler arasında yer almaktadır. Bu değişimin temel gerekçeleri arasında, idealizm ve esasicilik eğitim felsefesi akımlarının yerini ilerlemecilik felsefesi akımına bırakması ile çağdaş eğitim akımlarından biri olan çocuktan hareket akımının eğitim sistemlerini etkilemesi de yer almaktadır. Eğitim-öğretim sürecinin merkezinde kimin yer alması gerektiği konusundaki değişim, kelebek etkisiyle eğitim felsefelerinden öğretim modellerine, konu içeriklerinden sınıf yönetimine, öğretim-öğrenme yöntemlerinden ölçme ve değerlendirme yöntemlerine kadar geniş bir alanda değişimi ve buna bağlı olarak da güncelliği beraberinde getirmiştir. Bu değişim süreci, içerisinde öğrenme stillerinin de yer aldığı öğrenenlerin bireysel farklılıklarını daha fazla ön plana çıkarmaktadır.

Bilgi edinme sürecinde bireyin genel yeteneği, gelişimsel özellikleri, içerisinde bulunduğu toplumsal çevre, ön bilgileri, güdüsü, bilişsel süreçleri, duyguları, geçmiş yaşantıları, yaşadığı toplumun kültürü, ailesi vb. öğrenmeyi etkileyen değişkenlerdir. Var olan bütün bu etkenler bireyler için öğrenme yollarının ve bilgiye uyumun farklılaşmasına, böylece öğrenme sürecinde her bireyin öznel bir yaklaşım sergilemesine neden olması neticesinde her bireyin kendine özgü bir öğrenme stili ortaya çımaktadır (Erden \& Altun, 2006). Öğrenciler arasındaki bireysel farklılıklar üzerine yapılan araştırmalar öğrenme stili konusunun alanyazında yerini almaya başlamasına öncülük etmiştir (More, 1987). Öğrenme stilleriyle ilgili kavramlar, alanyazında ilk olarak öğrencilerin bilgi edinme sürecindeki var olan doğal farklılıklarını ortaya çıkarmak amacıyla 1890'lı yılların başlarında görünmeye başlamıştır. Ancak öğrenme stilleri konusunda önemli çalışmalar 1950'li yılların sonu ve 1970'li yılların başında yapılmaya başlanmıştır. Frank Riessman tarafından 1960'larda "öğrenme biçimi" terimi ile birlikte kullanılan öğrenme stili kavramı ilk olarak 1960 yılında Rita Dunn tarafından kullanılmaya başlanmış (Yazıcı ve Sulak, 2008), bu konuyla ilgili araştırmalar gerek sayı gerekse nitelik açısından 1980'li yıllardan sonra artmaya devam etmiştir. Eğitim sürecinde kullanılan öğretim ve öğrenme yöntemleri ile eğitim teknolojisinin öğrencilerin 
tamamında istenilen düzeyde olumlu gelişme meydana getirmemesi, öğrenme stilleri konusuna ağırlık verilmesi sürecinin önünü açmıştır (Evin Gencel, 2006).

\section{Stil ve Öğrenme Stili}

Alanyazında "stil" kavramının birbirlerine yakın anlamlı tanımlarına rastlamak mümkündür. Stil kavramı genel bir ifadeyle, "yetenek ile kişilik arasında bir bağlantıdır; bireyin yeteneklerini kullanmadaki tercihi, bilgi ve becerisini uygularken kullanmayı tercih ettiği yoldur" (Fer, 2005). Yetenek ile kişilik arasında bağlantı olan stil, bireylerin bir şeyi yaparken ya da düşünürken kullanmayı veya bireyin yeteneklerini kullanmadaki seçimi, bilgi ve becerisini uygularken tercih ettiği yoldur (Sternberg, 1997; Zhang ve Sternberg, 2000; Akt: Yıldız, 2010). Stil, bireyin kendine ait kişiliğiyle ve entelektüel iş görmesiyle ilgili olan genel niteliktir. Stil kavramı; spor dalları, sanat dalları, psikoloji ve eğitimle ilgili disiplinler gibi çok genel alanlarda kullanılabilir (Riding ve Rayner, 1998). Son dönemlerde stil kavramının kullanıldığı alanlardan biri de öğrenmedir. Alanyazında öğrenme stilleriyle ilgili ortak yanları ve benzer özellikleri çok olan ancak farklı tanımlar yer almaktadır.

Öğrenme stilleri kavramını ilk ortaya koyan Rita Dunn, öğrenme stillerini "her bir öğrencinin yeni ve zor bilgiyi öğrenmeye hazırlanırken, öğrenirken ve hatırlarken farklı ve kendilerine özgü yollar kullanması" şeklinde tanımlamıştır (Boydak, 2001). Konuyla ilgili çalışmalarıyla ön planda yer alan isimlerden biri olan Kolb, öğrenme stilini, bilgiyi alma ve işlemede kişisel olarak tercih edilen yöntem şeklinde tanımlamaktadır. Keefe (1979) ise öğrenme stilini “bireylerin öğrenme çevresini nasıl algıladıklarının, öğrenme çevresiyle nasıl etkileşimde bulunduklarının ve bu çevreye nasıl tepki verdiklerinin az çok istikrarlı göstergeleri olan bilişsel, duyuşsal ve fizyolojik özelliklerin örüntüsü" biçiminde tanımlamaktadır (Evin Gencel, 2006, 2007). Öğrenme stilleri konusunda model geliştiren bilim insanları arasında yer alan Dunn ve Dunn (1993) ise öğrenme stilini bireylerde farklılık gösteren, bireyin yeni veya zor bir bilgi üzerine yoğunlaşması ile başlayan bilgiyi alma ve bu bilgiyi belleğe yerleştirme süreciyle devam eden bir yol olarak tanımlamaktadır (Bilgin \& Bahar, 2008). Başka 
bir tanıma göre öğrenme stili, bireylerin bilgiyi toplama, düzenleme, düşünme ve yorumlama yöntemlerindeki tercihleri şeklinde açılanabilir (Davis, 1993; Akt: Güven, 2008). Yukarıda yer alan tanımalar dikkate alındığında, genel anlamda öğrenme stili "bir öğrencinin; doğuştan getirdiği, bilgiyi öğrenirken, hatırlarken veya kullanırken kendine özgü kullandığı yol, bilgiyi nasıl öğrendiğini ve öğrenmekten hoşlandığını gösteren bir durum, öğrenme sürecinde ve koşullarındaki eğilimleri veya tercihleri" şeklinde tanımlanabilir.

\section{Öğrenme Stillerinin Genel Özellikleri}

Bireysel farklılıklar, öğrenme stili ve akademik başarı, öğrenme stilleri ile biyolojik köken, öğrenme stilleriyle öğrenme strateji, yöntem ve teknikleri arasındaki ilişkinin genel özellikleri aşağıda yer almaktadır.

Bireysel farkhlıkların öğrenme ortamında kullanılması bir zenginliktir: Öğrenciler bireysel farklılıklardan dolayı farklı öğrenme ihtiyaçlarına ve stillerine sahiptir. Çünkü öğrenme stili, bireyin fiziksel ve duyuşsal ihtiyaçlarını etkileyen, çevresel ve algısal tercihlerinden meydana gelen bir bütündür. Her bireyin kişilik özellikleri, ihtiyaçları ve tercihleri birbirinden farklı olabilir. Bireye özgü olan bu özellikler gibi hiçbirinin bir diğerine üstünlüğü olmayan öğrenme stilleri de bireye özgü nitelikte bir bireysel farklılıktır (Erden ve Altun, 2006). Öğrenme stillerinin oluşumunda bireylerin ev, okul ve toplumdaki deneyimleri ve öğretmenin öğretme stili etkili olmakta; öğrencinin öğrenme stillerini belirleyen ögeler arasında mizaç, tarz, ilgi alanı, yetenek, çevre, zaman vb. faktörler yer almaktadır (Yenice ve Saracaloğlu, 2009). Öğrenme stili kavramı, öğrenmeye yaklaşımda öğrenciler arasındaki bireysel farklılıkların önemine dayalı olarak ortaya çıkmıştır. Öğrenme stillerinin temellerini oluşturan bireysel farklılıklar, arkadaş ilişkileri, meslek hayatı, aile, iş ve okul ortamı gibi bireyin iletişimde bulunduğu her yerde kendini gösterir. Eğitimin en önemli hedeflerinden biri, öğrenciye nasıl öğrenmesi gerektiğini, farklı öğrenme stillerini seçmeyi, uygulamayı ve bunları amacına göre kullanmayı öğretmektir.

Öğrenme stili mutlak anlamda değişmez değildir: Öğrenme stilleri konusunda önemli noktalardan biri de öğrencilerin mutlak anlamda değişmez 
bir öğrenme stiline sahip olmadıklarının bilinmesi gerçeğidir. Geçmiş deneyimlere, alışkanlıklara, sosyalleşmeye, kişiliklere, zeka türüne, cinsiyete, yaşa, aile, okula, kültürel unsurlara, rekabete ve başarı seviyelerine göre öğrenme stilleri farklılaşabilir (Kozhevnikov, 2007; Mitchell vd., 2009; Moss 1982; Jones ve diğ., 2003, Akt: Biçer, 2010). Öğrencilerin, öğrenme stili tercihleri zamanla değişebileceğinden, öğretmenler öğrencilerini belli tercihlere göre kesin sınıflara ayırmaktan kaçınmalıdırlar. Öğrencilerin belirli tercihleri olsa da bu tercihler zaman içerisinde değişebilmektedir. Zamanla, farklı durum ve görevlere uyum sağlayabilmek için öğrencilerin tercihleri değişebilir. Öğrenciler, öğrenme stillerine göre gruplandırılmasına rağmen bu durum öğrencilerin diğer öğrenme stillerine ait hiçbir özellik taşımadığı anlamına gelmemektedir. Öğretmenler öğrencilerinin farklı öğrenme stillerine uygun öğretim yöntemini uygulamalı ve öğrencilerini kendi öğrenme stili tercihlerini geliştirmeleri konusunda desteklemelidirler. Bunun yapılması ögrencilerin farklı durumlara daha kolay uyum sağlamalarına yardımcı olacaktır. Sadece bir öğrenme stiline saplanıp kalmış öğrenciler, farklı öğrenme stillerinin birleşimi ile başarılabilecek bir görevle karşılaştıklarında endişe duyarlar. Ayrıca öğretmenlerin öğrenme stillerine uygun öğretim yöntemlerini kullanmaları, kendi gelişmelerine ve yaratıcılıklarına da katkı sağlayabilir (Beck, 2001; Akt: Ural Alşan, 2009).

Öğrencinin öğrenme stilini bilmesi akademik başarısını artırır: Bireylerin öğrenme stilini bilmesi, öğrenme yaşantıları, stratejileri ve modelleri ile ilgili tercihleri hakkında bilgi sahibi olması, onun öğrenme sürecindeki güçlü ve zayıf yönlerinin farkına varmasına, dolayısıyla bu yönlerini geliştirecek türde çalışmalar yapmasına zemin hazırlamaktadır. Bu da öğrenenin okul ve yaşam sürecindeki başarısını olumlu yönde etkileyen bir durumdur. Bireyin kendisi için uygun öğrenme stilini bilmesi onun öğrenme gücünün arttırmasına yardım eder. Çünkü bireylerin öğrenmede başarılı olmaları, kendi bilişsel süreçlerinin farkına varmasıyla mümkündür. Dolayısıyla bireylerin öğrenme stillerini bilmesi, onların akademik ve günlük yaşamda daha başarılı olmasını sağlamak açısından önemli görülmektedir. (Aşkar ve Akkoyunlu, 1993; Ergür, 1998; Güven, 2004). Öğrenci özellikleri ile yöntem, ortam ve materyaller arasında uyum sağlayabilme- 
nin ilk aşaması, öğrenci grubunun özelliklerinin belirlenmesidir. Öğrencilerin bütün özelliklerini belirlemek mümkün ve pratik olmadığı gibi, bazı zaman ve durumlarda gerekli de değildir. Çünkü öğrencilerin bütün özellikleri, öğrenme üzerinde çok etkili değildir. Ancak öğrenme stilleri bunun dışında bir konudur (Heinich ve diğ., 2002; Akt: Usta ve diğ., 2011).

Bir bireyin öğrenme stilinde biyolojik köken baskındır: Bireyin öğrenme stilinin 3/5'inden fazlası biyolojik kökenlidir. Bu bakımdan öğretmenler de doğuştan gelen özelliklerinin yanı sıra büyük çoğunlukla nasıl öğrenmişlerse öyle öğretirler. Bu da öğretmenin öğretim stiline uymayan pek çok öğrencinin varlığını göstermektedir. Kaldı ki günümüz toplumlarında farklı eğitimsel deneyimlere ve kültürel geçmişe sahip öğrencilerden oluşan sinıflarda durum daha da ciddidir (Abidin ve diğ., 2011). Öğrenme bireysel olarak gerçekleşmektedir. Normal şartlar altında benzer standartlara sahip öğrenciler benzer veya aynı çevrede, okulda, sınıfta benzer yaşantıdan geçseler bile bu öğrencilerin öğrenme ve başarı düzeyleri birbirinden farklı olmaktadır. Bu durum öğrencilerin öğrenme stilleri ile öğretmenlerin öğretme stilleri başta olmak üzere, farklı bireysel özellikler ile açıklanabilir.

Öğrenme stili ve öğrenme stratejisi farklı kavramlardır: Burada dikkate edilmesi gereken nokta "stil ve stratejisi" kavramlarının birbirine karıştırılmaması gerçeğidir. Stil ve strateji birbirini tamamladığı zaman anlam kazanan birbirine yakın iki ayrı yapıdır. Stil kavramında biyolojik köken ağır basarken, stratejide planlama, önlem alma ve yol bulma gibi sosyal boyutlar ağırlıktadır. Öğrenme stilleri, kişilik düzeyinde özelliklerle s1nırlı bilgi işlem etkinliklerine karşılık gelir ve biyolojik kökenli olduğu için standarttır, değişimi zordur ve kişi çoğu zaman farkına varmadan kullanır. Öğrenme stratejisi ise bu özelliklerin dikkate alınarak çeşitli tekniklerin öğrenme sırasında kullanılmasıdır. Ancak farklı öğrenme süreçleri farklı öğrenme stratejilerinin uygulanmasını gerektirdiği için öğrenme stratejileri çeşitlendirilebilir veya gerekirse değiştirilebilir, duruma ve dersin amacına göre seçilebilir. Hangi öğrenme stiline sahip olduğunu bilen birey ise öğrenirken hangi stratejileri kullanacağını kestirebilir, planlar ve uygulamasını sağlar. Öğrencilerin öğrenme stratejilerini etkili olarak kul- 
lanmaları, kendi öğrenme stillerinin de farkında olmalarını gerektirmektedir. Öğrenme stiline uygun olmak koşuluyla bir birey çeşitli stratejileri kullanabilir (Babadoğan, 1994).

Öğretmek ve öğrenmek için birçok yol vardır: Herkes öğrenebilir ancak herkes aynı biçimde ve seviyede öğrenmez. Öğrenci merkezli ve bireysel farkların temel alınmasındaki en geçerli yollardan biri de öğretim süreçlerini öğrenme stillerine uygun düzenlemektir. Her öğrenciye uyan sihirli ve mutlak çözümlü tek bir öğrenme stili yoktur. Kimi öğrenciler sunulan öğrenme etkinliklerine katılmakla daha iyi öğrenirken ve bundan hoşlanırken, kimi öğrenciler ise etkinliklere katılma konusunda çekimser olabilir (Sünbül, 2011). Eğer bireylerin öğrenme stillerinin ne olduğu belirlenirse bu bireylerin nasıl öğrenebilecekleri ve onlara nasıl bir öğretim tasarımı uygulanabileceği de daha kolay biçimde kestirilebilir. Böylece, öğretmen hem kendisi hem de öğrenciler için uygun ortamlar hazırlayabilir. Öğretim programının bir ögesi olan öğrenme-öğretme sürecinde öğrencilere, oluşturulan hedefleri kazandırabilmek için, geçirmeleri gereken öğrenme yaşantılarını sağlayacak dış koşulların düzenlenip işe koşulması ve öğrencilerden öğrenmesi beklenilen davranışların gelişebilmesi için yaşantıların etkili şekilde organize edilmesi gerekmektedir (Demirel, 2012). Bu amaçla, öğrenme-öğretme süreçlerinin yeni veya güncel yaklaşımlarla ve öğrencilerin öğrenme stillerine uygun olarak hazırlanılması gerekmektedir.

Öğrenme stilini bilmek öğretim yöntem ve teknik seçimine etki eder: Öğrencilerin öğrenme stilinin bilinmesi işlevsel ve uygun öğrenme model, strateji, yöntem ve tekniklerin seçilmesine ve kullanılmasına zemin hazırlamaktadır (Peker, 2003a; Taşpınar, 2012). Bu durum farklı öğrenme stiline sahip öğrenciler için çeşitli organizasyonların ve etkinliklerin sergilenmesine; eğitim sisteminin verimliliği, kalitesi ve kalıcılığının olumlu yönde geliştirilmesine katkı sağlamaktadır (Karakuyu ve Tortop, 2010). Konuyla ilgili olarak Akkoyunlu (1995), öğrencilerin öğrenme stillerinin belirlenmesinin, öğretmenlerin kullanacağı öğretim yöntem ve teknikleri seçimine olumlu etkisinin olduğunu vurgulamaktadır. Eğitim sürecinde öğretim modelleri, stratejileri, ilke ve yöntemleri ile öğrenme stilleri anahtar rol oynayan önemli faktörlerdir. Alanyazında yer alan pek çok çalışma, 
öğrencilerin öğrenme stillerine uygun öğretim yöntemlerini kullanmanın öğrencilerin akademik başarısının artmasına yardımcı olduğunu somut olarak ortaya koymaktadır. Bu bakımdan öğrenme stilleri ile çeşitli öğretim yöntemleri arasındaki etkileşimin anlaşılması, eğitim-öğretim sürecinin anlaşılmasına yardımcı olmasının yanı sıra bu sürecin geliştirilmesine de katkı sunarak daha etkili bir öğretim tasarımının yapılmasına da imkân tanıyacaktır (Kumar, Kumar ve Smart, 2004). Eğitimde başarının önemli anahtarlarından biri, öğrenciyi tanımaktır. Öğrencinin öğrenme stillerini bilmeden uygulanan öğretim yöntem ve teknikleriyle hedefe ve başarıya istenilen düzeyde ulaşılması zorlaşabilir. Öte yandan öğrencilerin öğrenme stilleri esnektir ve sinıf deneyimlerinin sonucunda zamanla değişebilir. Örneğin, öğretmen çok sayıda işbirlikli öğrenme tekniği kullanıyor ve öğrencilerine işbirlikli çalışmayla yapabilecekleri ödevler veriyorsa bu durum öğrencilerin işbirlikli öğrenme stillerinin güçlendirilmesine katkı sağlayacaktır (Grasha, 1996; Akt: Ural Alşan, 2009).

Öğrenme ve öğretim stilleri uyumlu olmalıdır: Öğrencilerin farklı öğrenme stillerine sahip olduklarının göz önüne alınmaması, çoğu zaman öğrencilerin bu gereksinimlerini karşılamada başarısızlıkla karşı karşıya kalınmasına sebep olmaktadır. Sonuç olarak öğretmenin öğretme stili ile uyumlu olan öğrenciler başarılı olmakta, diğer öğrenciler ise başarısız olabilmektedir. Bu nedenle, etkili bir öğrenmenin gerçekleşebilmesi için öğretmenlerin öğrencilerin öğrenme stillerinin ne olduğunu bilmesi gerekmektedir. Öğretmenler öğretim etkinliklerini planlarken, eğitim ortamlarını düzenlerken, eğitim ortamında kullanılacak araçları ve gereçleri seçerken, çalışma kümelerini oluştururken ve çalışmalara rehberlik yaparken öğrencilerin öğrenme stillerini göz önünde bulundurmalıdır (Özer, 1998).

Öğrenme stili açısından her birey farklı velveya birden fazla stile sahip olabilir: Bireylerin öğrenme stili birbirlerinden farklı olabilir. Öğrenme stilleri yaş, cinsiyet, kültür, akademik başarı düzeyi, bilgi edinme süreçlerindeki tercihler gibi değişkenlere göre değişiklik gösterebilir (Özer, 1998). Öte yandan bir birey, birden fazla öğrenme stiline da sahip olabilir ve sahip olduğu bu öğrenme stillerini farklı derecelerde kullanabilir. 


\section{Öğrenme Stili Modelleri}

Öğrenme stillerinin tanımlarında da anlaşılacağı üzere pek çok değişken öğrenme stilleriyle iç içedir veya öğrenme stilini etkilemektedir. Bu durum, konuyla çalışma yapan bilim insanlarının öğrenme stillerinin benzer ve farklı yönlerine vurgu yapmalarına, öğrenme stillerinin farklı boyutların ele almalarına, bazı noktalarda birbirilerine benzemelerine veya ortak özelliklerinin bulunmasına rağmen birçok öğrenme stili modelinin ortaya çıkmasına, kısaca öğrenme stillerinin tanımlarındaki farklı değişkenlere bağlı olarak farklı modeller ortaya konmasına zemin hazırlamıştır. Farklı öğrenme stilli modellerinin ortaya çıkmasında her bir öğrenme stilinin biyolojik, sosyolojik, çevresel, kişisel, bilişsel, duyuşsal, fizyolojik vb. özelliklere diğerlerinden daha fazla ağrılık vermesi de etkili olmuştur. Bu noktada De Bello (1990), birçok öğrenme stili modelinin birbiriyle örtüştüğünü ancak bazı öğrenme stili modellerinin bilişsel, duyuşsal ve devişsel gibi (çok boyutlu) davranışsal özelliklerin tümüne birden dayanıyorken, bazılarının ise sadece bilişsel ya da psikolojik gibi tek boyutla sınırlı kaldığını belirtmektedir (Yavuzalp ve Gürol, 2017). Alanyazındaki öğrenme stilleriyle ilgili sınıflamaların bazıları, örneğin Junk ve Kolb, özgün yaklaşımlar ile geliştirilmiş olsa da büyük çoğunluğu kendisinden önce yapılan veya geliştirilen öğrenme stili modellerini temel veya örnek aldığı söylenebilir.

\section{Tablo 1. Öğrenme Stili Modelleri}

\begin{tabular}{llll}
\hline 1 & Jung'un psikolojik tipler kuramı & 16 & Barsch öğrenme stili \\
2 & Myers \& Briggs tip göstergesi & 17 & Brandt öğrenme stilleri \\
3 & Lawrance öğrenme stili & 18 & Butler öğrenme stili \\
4 & Fleming \& Mill öğrenme stili & 19 & Hermann'ın beyinsel baskınlık \\
5 & Reinert öğrenme stili & 20 & Hill bilişsel öğrenme stili \\
6 & Kolb'un öğrenme stili & 21 & Kagan'ın bilişsel stili \\
7 & Honey \& Mumford öğrenme stili & 22 & Keirsey \& Bates stili \\
8 & 4MAT öğrenme stilleri & 23 & Letteri öğrenme stilleri \\
9 & Grasha-Riechmann öğrenme stili & 24 & Merril sosyal stilleri \\
10 & Dunn \& Dunn öğrenme stili & 25 & NASSP öğrenme stili \\
11 & Felder \& Silverman öğrenme stili & 26 & Riding \& Cheema'nın bilişsel stil \\
12 & Alan bağımlı-bağımsız öğrenme & 27 & Silver \& Hanson öğrenme stili \\
13 & Gregorc öğrenme stili & 28 & Simon \& Byram öğrenci tipleri \\
14 & Canfield öğrenme stili & 29 & Torrance öğrenme stilleri \\
15 & Curry öğrenme stili & 30 & Witkin'in bilişsel stili \\
\hline
\end{tabular}


Alanyazında yer alan ve bilinen öğrenme stili modelleri Tablo 1'de yer almaktadır. Çalışma kapsamında bunlar içerisinden en tanınmış ve bilinen ilk 14 öğrenme stilli modellerine detaylı yer verilmiştir.

\section{Jung'un Psikolojik Tipler Kuramı}

Jung "Psikolojik Tipler" adlı kitabında insanların bilgiyi algılama ve işleme yollarındaki farklılıkları ele almıştır. Carl Jung'ın "kişilik tipleri kuramı"nın öğrenme stilleriyle ilgili çalışmaların temelini oluşturduğu belirtilmektedir. Jung, bireylerin nesnel ve öznel dünyası olduğunu ileri sürmektedir. Öznel dünya kişiliğin tamamını tanımlayan içsel ve kendine özgü psikolojik durumlarını; nesnel dünya ise kişinin çevresindeki insanları, kuralları, gelenekleri, ekonomik ve toplumsal kurumları, doğa koşullarını içermektedir. Buna bağlı olarak bireylerde dışadönüklük ve içedönüklük olarak iki temel özellik meydana gelmektedir (Jung, 1977; Akt: Evin Gencel, 2006). Dişadönük ve içedönük karakter tiplerinin genel özellikleri Tablo 2' de yer almaktadır.

\section{Tablo 2. Jung'un Karakter Tipleri}

\begin{tabular}{ll}
\hline Dışadönük & İçedönük \\
Dışa dönüktür. & Utangaçtır. \\
Çabuk kırılıaz. & Kendisine dönüktür. \\
İşlerinde geç kalmaz. & Anı, hayaller dünyasında yasar. \\
Kararsızlık göstermez. & Çevresine uymakta güçlük çeker. \\
Değişiklikleri, yenilikleri sever. & Bir şey yapmaya başlamadan önce uzun uzun \\
Zorluklar karsısında cesaretini kaybetmez. & düşünür. \\
İşle ilgili düşüncelerini sonraya bırakır. & Karar vermede zorlanır, zaman kaybeder, işin \\
Beklemenin bir yarar sağlamayacağını düşü- & gecikmesine neden olur. \\
nür. & Kendisine ve başkasına güvenmez, bunun so- \\
Genel olarak, önce tasarladığı iş̧i yapmaya & nucu olarak, başkalarıyla zorlukla kurduğu \\
baslar. & ilişkilerde kuşku duyar. \\
Dış dünyayla olumlu, yaratıcı iliş̧kiler kur- & Yapacağı işin sonuçlarını kendi kendine tartı- \\
makta güçlükle karşılaşmaz. & şır, sakıncalı yanların olup olmadığını anla- \\
& maya çalışır. \\
\hline
\end{tabular}

Kaynak: Özgü, 1976 ve Daco, 1983'den uyarlayan Veznedaroğlu ve Özgür 2005.

Jung'ın kitabında psikolojik tipler dört kategoride ele alınmış olup bu tiplerin genel özelliklerine aşağıda yer verilmiştir (Sever, 2008). 
Hissedenler: Önem verdikleri değerleri yaşanmalarına aktarırlar. Böylece zihinleriyle çelişen ama hisleriyle uyum içinde algıladıklarını ve kendileri için yapılanları değerlendirirler. Aktif hissetme, yapacakları bir eylemle doğrudan ilişkili olduğu için bilinçli bir süreçtir. Bu süreç, genelde mantık kurallarına uygun bir şekilde belirlenmektedir.

Düşünenler: Bir şeyin anlamının ne olduğunun fark edilmesini sağlamaktadır. Düşünenler, mantıklı hareket eder ve düşünmeyle meşgul olurlar. Algıladıklarını ve olayları, mantıklı kategoriler içerisinde organize ederler. $\mathrm{Bu}$ arada mantıklı kategorileri ve bu kategorilerin içeriklerini bilinçli olarak kontrol etmekte ve bir değerlendirme yapmaktadırlar.

Algılayıcılar: Bu kişiler bilinçli bir şekilde algılamaktadırlar. Fakat ne hissedenler gibi hissettiklerine önem verirler ne de düşünenler gibi kategorilere uyum sağlamaktadırlar. Olumlu bir özellik olarak bilinçli olan bu bireyler, olumsuz bir özellik olarak ise duygularını açığa vururken etkili bir kontrol uygulayamazlar ve kontrolsüzdürler.

Sezgililer: Sezgi, onlar için olabilecek meydan gelebilecek ihtimalleri göstermektedir. Sezgili bireyler algıladıklarını bilinçsiz bir şekilde kontrol etmektedirler. Bu bireyler gördüklerini, hissettiklerini tam ve bütün olarak algılarlar. İçü̈düsel olarak anlamaktadırlar.

\section{Myers E Briggs Tip Göstergesi Modeli}

Isabelle Myers ve Katherine Briggs (1962), Jung'un sınıflamasının eğitim alanında pratik bir kullanımını oluşturmak için "Myers-Briggs tip belirleyicisi ölçeğini" (MBTI-Myers-Briggs Type Indicator) geliştirmişlerdir. Jung'ın teorisine dayanan ve psikometrik bir ölçme aracı olan MBTI, bireyleri kişisel öncelik ve tercihlerine göre sınıflandırmada, değişik kişilik tercihlerini ortaya koymaktadır (Güneş ve Gökçek, 2012). Ölçekte, her biri birbirine zıt göstergelere ayrılan, dışadönük-içedönük, duyusal-sezgisel, düşünsel-duygusal ve yargisal-algısal olmak üzere dört temel kişilik özelliği yer almaktadır. Turan, Şahin ve Altın (2018), konuyla ilgili alanyazın taraması sonucu bu kişiliklerin temel özelliklerini şöyle belirtmektedir: 
Dışa dönük $\mathcal{E}$ içe dönük: Bireyin diğer bireylerle nasıl ilişki kurduğunu, iç ve diş dünyası arasındaki tercihi (enerjisini içten mi yoksa dıştan mı sağladığını) temsil eder. Dışa dönükler; sosyal, dış dünyaya ait kişi, nesne ve olaylara ilgi duyan, eylem odaklı, düzenli ve nesnel iken, içe dönükler; iç dünyasına ait anlam, kavram ve fikirlere ilgi duyan, düşünce odakll, okumayı seven, detaylara önem veren, yalnızlıktan hoşlanan utangaç ve öznel kişilerdir.

Duyusal \& sezgisel: Bireyin dünyayı nasıl algıladığını, nasıl bilgi edindiğini, daha çok duyularını mı yoksa sezgilerini mi kullandığını açılar. Duyusallar; duyu organlarıla algılanabilen, gerçek, somut nesnelerle ilgili olup bu organlarını iyi kullanabilen kişiler iken, sezgiseller; objektif olmayan, bilinçdışı algı süreçlerine daha fazla güvenen, soyutla ilgilenen kişilerdir.

Düşünsel E duygusal: Bireyin düşünerek mi yoksa duygularıla mı karar verdiğini açıklar. Düşünseller; sebep sonuç ilişkisine dayalı, akıl ve mantıklarına göre karar veren kişiler iken, duygusallar; öznel süreçlere dayanan, olayların kendileri için taşıdığı değerlere göre karar veren kişilerdir.

Yargısal \& algısal: Bireyin hayatını yargılayarak mı, algılayarak mı yönlendirdiğini açıklar. Yargısallar; sonuç odaklı, düşünce ve hislerin bir birleşimini kullanarak olayları kontrol altında tutmak isteyip daha düzenli bir yaşam tarzı benimserken, algısallar; süreç odaklı, sezgi süreçlerini kullanarak olayları anlayıp yaşamı keşfetmek isteyen, daha fazla veri toplayan, alternatif arayan ve daha esnek bir yaşam tarzı benimseyen kişilerdir.

\section{Lawrance Öğrenme Tipi Modeli}

Isabel Myers' in çalışmalarını temele alarak Lawrance (1982), Carl Jung'un dört öğrenme boyutuyla şekillendirdiği düşünenden hissedene, kişinin değer ve sorumlulukları; dışa dönükten içe dönüğe, kişinin doğal ilgileri; eleştiriciden algılayıcıya, kişinin çalışma alışkanlıkları duyguludan sezgiliye, kişinin somut ya da soyut tercihlerinden meydana öğrenme tipi tanımlamaları yapmıştır. Lawrance öğrenme tipi modeline yer alan dört tip sınıflama aşağıdaki gibidir (Akdeniz, 2007): 
Duygulu tipler: İşleri kurulu olduğu şekliyle yapmayı seven bu tipler genellikle sonuçlara adım adım ulaşırlar. Titizlik gerektiren ve hassas işlerde iyi olma ve çalışma süresi önceden belirlendiğinde daha sabırlı çalışma eğiliminde olurlar.

Hisseden tipler: Diğer insanlarla ve onların duygularılya oldukça fazla ilgilidirler. İnsanları en olmadık durum ve zamanlarda dahi hoş tutmayı ve insanlarla uyumu severler. Öte yandan diğer insanlarla uyuma ihtiyaç duyarlar. İnsanlarla iç içedirler ve sempatik olan bu tipler genelde kararlarının başkaları tarafından etkilenmesine fırsat tanırlar.

Sezgili tipler: Problem çözmekten hoşlanır ve sonuçlara oldukça hızlı ulaşırlar. İyi ya da kötü, ilhamlarına göre hareket eden bu tipler, karmaşıklıklarda sabırlı olup molalarda dahi enerjik bir şekilde çalışmaya devam ederler.

Düşünen tipler: İşleri mantıklı bir sıraya koyup analiz etmelerine rağmen duygularını rahatlıkla ifade edemezler. Kararlarında kişisellikten çok toplumu önceleyen bu tipler adil davranılma konusunda hassas ve katı fikirlidirler.

\section{Fleming E Mill Öğrenme Stili Modeli (VARK)}

VARK modeli olarak da bilinen "görsel, işitsel, okuma-yazma, kinestetik öğrenme stili modeli", Neil Fleming (1987) tarafından geliştirmiştir. Bu model Gardner'in çoklu zekâ kuramı ile benzer özelliklere sahiptir. VARK modelindeki tercihler, Gardner'da zekâ olarak belirtilmektedir. VARK başlı başına bir öğrenme stili olmayıp aynı zamanda bilginin algılanışı üzerine yoğunlaşır. Öğrenme stilleri alanyazını incelendiğinde Fleming'in yazılı eserleri “farklıyım, aptal değil!” özeti ile kendini göstermektedir. İngilizce olarak kısaltılan VARK'ın açılımı aşağıdaki gibidir (Arslangilay, 2015)
Visual (görsel)
Aural (işitsel)
Read -write (okuma-yazma)
Kinesthetic (dokunsal/devinsel) 
Bazı kaynaklarda ise okuma-yazma ayrı bir öğrenme stili olarak ele alınmamış olup, bu model kısaca VAK (visual-görsel), aural-işitsel) ve kinesthetic-devinsel) olarak sinıflandırılmıştır. Modelde yer alan öğrenme stilleri, bu stillerin genel özellikleri ve çalışma şekli şöyledir (Yetim, 2008):

Görsel öğrenme stili: Gösteriler, filmler, resimler, diyagramlar, vb. içeren yani görülen ve gözlenen şeyleri kullanmayı gerektirir. Bu öğrenme stiline sahip insanlar, bilgi görsel ve yazılı bir şekilde sunulduğunda en iyi şekilde öğrenirler. Bir sınıf ortamında konuyla ilgili anahtar kavramları ve önemli noktaları göstermek için yazı tahtası, powerpoint sunumları gibi görsel unsurları kullanan öğretmenlerden iyi şekilde öğrenirler. Ders kitaplarındaki ve notlardaki bilgiler, öğrenmeleri açısından önemlidir. Bu tip öğrenenler, sessiz ortamda ve yalnız çalışmaktan hoşlanırlar. Öğrendiği bilgiyi hatırlamak için onu zihinlerinde canlandırırlar. Görsel öğrenenin karakteristik özellikleri şu şekilde ifade edilebilir:

- Okuyucu ve gözlemcidir, genellikle ayrıntılı not tutar.

- Sürekli konuşulmasından ve anlatılmasından hoşlanmaz.

- Her şeyi görmek ister ve gözden geçirir, görsel uyarıcılardan hoşlanır.

- Tam öğrenmek için öğretmenin jest ve mimiklerinin görme ihtiyacı duyar.

- Bir kelime, bir koku veya bir ses bir şeyi hatırlamasına ve zihinsel olarak uyarılmasına yardımcı olur.

- En iyi görsel sunumlar yoluyla öğrenir, haritalar, resimler, diyagramlar ve renkler öğrenmesinde kolaylık sağlar.

Görsel öğrenenin çalışma sekli şu şekilde ifade edilebilir: Öğretmenlerinin vücut dilini ve yüz ifadelerini görerek onlarla konuştuklarında olaylara öğretmenlerinin bakış açısından bakabilirler. Metindeki önemli noktaları vurgulamak için renkli kalemlerle altını çizerler. Düşüncelerle ilgili zihinlerinde betimleme yaparlar ve kavram haritaları kullanırlar. Bilgisayar, video vb. gibi kitle iletişim araçlarını kullanırlar. Sesten ve gürültüden uzak sessiz ortamlarda çalışırlar. Derse aktif olarak katılırlar. Çünkü bu onların derse olan ilgisini ve dikkatini canlı tutar. Bir konuyu ya da konudaki kavramı öğrenmek için onu tekrar tekrar yazar. İyi fikirleri hatırlamak için not alırlar. 
İşitsel öğrenme stili: Kendi kendine konuşma ve diğerlerini dinleme yoluyla bilginin transfer edilmesini ve yorumlanmasını içerir. Bu insanlar, bilgi sözel olarak sunulduğu zaman en iyi şekilde öğrenirler. Bir sınıf ortamında, dersi dinleyerek ve grup tartışmalarına katılarak öğrenirler. Ayrıca, ses kasetlerine veya CD'lere kaydedilen bilgileri tekrar dinleme yoluyla öğrenirler. Bir şeyi hatırlamaya çalıştıklarında, genellikle onu yüksek sesle tekrar ederler ve onlara bilginin açılanış şeklini zihinlerinde duyabilirler. İşitsel öğrenenin karakteristik özellikleri şu şekilde ifade edilebilir:

- Nadiren bazı şeyleri not alırlar.

- Sözel açıklamaları ve sözlü verilen yönergelere öncelik verirler.

- Ödevleri yapmayı değil, onun hakkında konuşmayı tercih ederler.

- Derste anlatılanlarla ilgili kendi kendine konuşarak tekrar yaparlar.

- Ses tonu ve perdesi, konuşma hızı vb. ince ayrıntıları dinleyerek konuşmanın altındaki temel anlamları yorumlarlar.

İşitsel öğrenenin çalışma sekli şu şekilde ifade edilebilir: Yüksek sesle düşünürler ve kendi kendine konuşurlar. Sınıf tartışmalarına katılırlar. Konuşmalar ve sözlü sunumlar yaparlar. Özellikle tekrar yaptıklarında bir metni yüksek sesle okurlar. Öğrenmelerine yardım etmek için müziksel tekerlemeler ya da şarkılar yaratırlar. Teyp kayıtlarını kullanırlar. Bir arkadaşı veya bir grupla düşüncelerini tartışarak öğrenmekten hoşlanırlar. Sözel analojileri kullanırlar. Konuyu daha iyi öğrenmek için tekrar anlatırlar. Derste, görsel uyarıcılar az kullanılırsa sınıfın arkasında veya arkaya yakın bir yerde oturmak isteyebilirler.

Kinestetik Öğrenme Stili: Fiziksel deneyimi yani dokunma, hissetme, tutma, yapma ve uygulama yoluyla elde edilen deneyimleri içerir. Kinestetik kelimesi, kas hareketlerini kullanma duyusu şeklinde tanımlanır. Başka bir deyişle, fiziksel duyuyu ifade eder. Bu nedenle, kinestetik öğrenme vücudun kasları, eklemleri ve sinirlerin uyarılmasıyla ilgili öğrenme olarak tanımlanır. Bu insanlar, fiziksel olarak bir faaliyeti yaptıkları zaman en iyi şeklide öğrenirler. Sınıf ortamında, materyalleri kullandıkları ve onlarla deneme yaptıkları zaman iyi şekilde öğrenirler. Öğrenmeleri için sınıftaki faaliyetlere aktif olarak katılmaları gerekir. Sınıfta, gösteri yapan, öğrencilerine ilk elden öğrenme deneyimleri sunan ve sınıf d1şında alan çalışması yaptıran öğretmenlerden en iyi şekilde öğrenirler. 
Dokunsal/kinestetik öğrenenin karakteristik özellikleri şu şekilde ifade edilebilir:

- Proje, plan, taslak hazırlamada iyidirler.

- Maceracıdırlar, uzun süre oturmaktan sıkılırlar.

- Dinlerken düşünerek analiz yaparlar ve bu yolla bilgiyi işlerler.

- Ellerini kullanarak konuşurlar ve parmaklarıyla hesaplama yaparlar.

- Herhangi bir konu hakkında çalışırken ya da konuyu bir başkasından dinlerken konuyla ilgili materyale dokunmak, materyali ele almak ve hareket ettirmek ihtiyacı duyarlar.

Dokunsal/kinestetik öğrenenin çalışma sekli şu şekilde ifade edilebilir: Çalışırken sık sık ara verirler ve bir etkinlikten bir başkasına geçerler. Bir konuyu öğrenirken bedenini kullanarak ve ayakta durarak öğrenirler. Konuyu okurken önemli noktaları vurgulamak için parlak kalemlerle altını çizerler. Çalışırken müzik dinlerler. İlk olarak, bir metninin tamamını gözden geçirirler ve ondan sonra metni dikkatli bir şekilde bölüm bölüm okurlar. Zihin haritaları gibi uzamsal not alma tekniklerini kullanırlar. Karmaşık projelere başlamadan önce yapılması gerekenleri başlangıcından sonuna kadar önce zihinlerinde canlandırırlar ve ondan sonra projeyi yapmaya başlarlar. Bu resmin tamamını zihinlerinde görmelerini sağlar.

VARK öğrenme stili modeline göre kendi öğrenme stilini belirleyen bir öğretmenin tercih ettiği etkinlikler ve kullandığ 1 stratejiler şu şekilde özetlenebilir (Allen vd. 2010; Akt: Arslangilay, 2015)

a) Görsel: Bu tarz öğrenme stiline sahip öğretmenler öğrencilerine bir şeyler açıklarken görsel araçlar kullanırlar. Kavram haritaları, diyagramlar, modeller, akış diyagramları, bilgisayar animasyonları, videolar, slaytlar, tartışmaları yorumlama, netleştirme ya da yönlendirme için de fotoğraflar kullanabilirler. Sınav sorularında kullandıkları sözcükler şunlardır: "Göster, açıkla, karşılaştır, resimle."

b) İsitssel: Bu tarz öğrenme stiline sahip olan öğretmenler; seminerler, sözlü sınavlar, grup sunumları yaptırmayı tercih ederler. Sınıf tartışmaları, ses kasetleri, düşün-eşleş-paylaş etkinliği (verilen konu ile ilgili önce bağımsız düşünen öğrenciler daha sonra eşler halinde düşüncelerini paylaşır ve en son olarak da tüm sınıfla paylaşırlar) bu stile sahip öğretmenlerin tercih ettiği etkinlikler arasında yer almaktadır. Yapacakları açıklamalarda ses kasetleri, telefon görüşmeleri, karşılıklı 
konuşmalar yaptırma gibi uygulamalar kullanan bu öğretmenlerin s1nav sorularında kullandıkları sözcükler şunlardır: "Açıkla, tanımla, tartış ve ifade et."

c) Okuma-yazma: Bu tarz öğrenme stiline sahip öğretmenler öğrencilerine konuları anlatırken tahtaya yazarlar. Sınıfta bir makaleyi tartışmadan önce mutlaka onu okuyan bu öğretmenler, önemli sözcükleri de tahtaya yazarlar. Akranların birbirlerinin notların değerlendirmesi, günlükler, özetler gibi uygulamalar yaptıran bu öğretmenlerin sınav sorularında kullandıkları sözcükler şunlardır: "Analiz et, haklı göster, doğrula ve tanımla."

d) Kinestetik: $\mathrm{Bu}$ tarz öğrenme stiline sahip öğretmenler öğrencilerine bir şeyi açıklarken gerçek hayattan örnekler sunar. Sınıflarına misafir konuşmacılar çağırır, öğrencilerini alan gezilerine götürür, metafor tekniği kullanır. Bu öğretmen sınıfında ayrıca rol oynama, fiziksel sunumlar, ayağa kalk-otur etkinliği (sınıftaki öğrencilerin birbirlerini daha iyi tanıabilmeleri için, hareketli bir etkinliktir. Mesela öğretmen; "kız kardeşi olanlar ayağa kalksın, en sevdiği renk kırmızı olanlar ayağa kalksın" gibi sorular sorar) gibi etkinlikler kullanmayı tercih eder. Sınav sorularında kullandıkları sözcükler ise "uygula, göster, deneyimle, gösteri yap"tır.

\section{Reinert Öğrenme Stili Modeli}

Reinert (1976), öğrenme stilleri ile ilgili çalışmasında bilişsel becerilerin gelişimine odaklanmıştır. Reinert, öğrenme stillerini işiterek, görerek, sözlü semboller ve hareket temelli olarak dört grupta sınıflandırmıştır. Bu öğrenme stiline sahip olan öğrencilerin genel özelliklerine aşağıda yer verilmiştir (Riding ve Rayner, 1998; Akt: Boydak, 2001; Sever, 2008):

Görerek öğrenenler: Görme duyusunu çok kullanarak öğrenmeyi tercih etmektedir. Bu öğrenme stilinde yer alan öğrencilerin genel özellikleri şöyle siralanabilir:

- Ayrıntıları ve renkleri çok iyi hatırlama,

- Gösterileri izlemekten (öğrenirken) hoşlanma,

- Okumaktan ve yazmaktan hoşlanma, hızlı okuma,

- Başlamakta yavaş olma, not almak ve liste yapma, 
- İnsanların adlarını unutma, ama yüzlerini hatırlama,

- Düşünceleri düzenlemede grafiksel malzeme hazırlama,

- Problemleri çözerken talimatları okuma, problemleri listeleme,

- Öğrenirken öğrenilecek bilgileri okuma, akış kartları kullanma,

- Sözlü yönlendirmeler yapılırken diğerlerinin ne yaptığına bakma,

- Görülen isimleri hatırlama, görsel materyallerle öğrenmek isteme,

- Uzun süre çalışma, sessiz ortamı sevme, kelimelerin yazılışını hatırlama,

- Özetleri göz ardı etme ve yazılı sınavlardan genelde daha başarılı olma,

- Harita okuyabilme, grafiksel çalışmaları görme ve zihinde canlandirma.

İşiterek öğrenenler: İşitme duyusu ile öğrenmeyi daha fazla tercih etmektedir. İşiterek öğrenen öğrencilerin özellikleri şu biçimde sıralanabilir:

- Sözlü sınavlarda başarılı olma, akıcı ve düzgün konuşması,

- Bir öğretmeni dinleyerek, grup tartışması yaparak öğrenmesi,

- Görsel konularda dikkatin azalması, görsel belleğin zayıf olması,

- Problem çözerken başkalarıyla ve kendileriyle konuşmayı sevmesi,

- Sesli okumada anlamanın, sessiz okumadan daha iyi gerçekleşmesi,

- Çalışma ortamında hafif sesli ortam istemesi, okurken dikkatli olmasi,

- Hafif sesli ortamı ve sesli okumayı sevmesi, dudaklarını kıpırdatması,

- Harita, çizelge vb. okurken güçlük çekme, sözcük kartlarını tercih etmesi.

Sözel sembollerle öğrenenler: Öğrenmede sözel öğeleri daha fazla tercih eden bu öğrenme stiline sahip öğrenenlerin genel özellikleri şunlardır:

- Sözcüklere fazla önem verme, sözel şekilde özetleme,

- Görme ve işitmeden ziyade sözlü sembolleri daha çok sevme,

- Yazarken ters biçime dönüş̧ürebilme, bir şeyi tekrarlayarak öğrenme,

- Akıcı, düzgün konuşma, konuşmayı sevme, sözcükleri işlevsel kullanma

- Görsel, işitsel konuda dikkat seviyesi düşük olma ancak sözcük oyunlarından hoşlanma. 
Hareket temelli öğrenenler: Öğrenmede daha çok dokunma duyusundan yararlanmaktadır. Bu öğrencilerin sahip olduğu özellikler şunlardır:

- Aletleri kısımlarına ayırarak tekrar birleştirebilme,

- Uzun süre dinleyememe, başkalarının sözünü kesme,

- Testte veya yaptığı işlerde değerlendirilirse daha başarılı olma,

- Dokunulmaktan ve kucaklanmaktan hoşlanma, sporda iyi olma,

- Yaparak yaşayarak öğrenme, aldığı notları evde yeniden yazma,

- Kendi hızında ilerleme, çalışırken sık sık ara vermeye ihtiyaç duyma,

- Sürekli bir şeyler yazma, çok hızlı konuşma, okurken ayaklarını sallama,

- Aceleleri varmış gibi görünme, konforlu ve güvenli ortamı tercih etme.

\section{Kolb'un Öğrenme Stili Modeli}

Modelin temeli, Kolb'un (1984) deneyimsel öğrenme kuramı'na (experiential learning theory) dayanmaktadır. Deneyimsel öğrenme kuramı sadece öğrenme stillerini ortaya koyma değil, öğrenme ve bireysel gelişme ile ilgili temel soruları da cevaplama amacını taşımaktadır. Kolb öğrenme stili modelinde bireylerin öğrenme stilleri bir döngü şekildedir. Bu döngü içerisinde dört öğrenme biçimi (yolu, aşaması) bulunmaktadır. Bunlar somut yaşantı (SY), yansıtıcı gözlem (YG), soyut kavramsallaştırma (SK) ve aktif yaşantıdır (AY). Kolb’a göre öğrenciler bir konuyu öğrenirken dört öğrenme aşamasından da geçmelidir. Öğrenme döngüsü öncelikle somut deneyimden (yaşantıdan) yansıtıcı gözleme, sonra da soyut kavramsallaştırmadan aktif deneyime doğru yapılandırılmalıdır. Kolb’a göre öğrenme sürecinin iki temel boyutu bulunmaktadır. Birincisi soyut kavramsallaştırmadan somut yaşantıya, ikincisi ise aktif yaşantıdan yansıtıcı gözleme uzanmaktadır. Kolb öğrenme stili modelinde somut yaşantı ve soyut kavramsallaştırma bireyin bilgiyi nasıl algıladığını, yansıtıcı gözlem ve aktif yaşantı bireyin bilgiyi nasıl işlediğini açıklar. Her bir öğrenme biçimini simgeleyen öğrenme yollarındaki tercihleri birbirinden farklıdır. Bunlar sırasıyla somut yaşantı için "hissederek", yansıtıcı gözlem için "izleyerek", soyut kavramsallaştırma için "düşünerek" ve aktif yaşantı için "yaparak" öğrenmedir. Kolb’un öğrenme stili modeline göre bireyler bilgiyi 
düşünerek ve hissederek algilar, yaparak ve izleyerek işlerler. Bireyin öğrenme stilini tek bir yetenek belirlememektedir. Her bireyin öğrenme stili, dört öğrenme biçiminin bileşenidir (Kolb, 1984; Akt: Ekici, 2003; Karademir ve Tezel, 2010). Kolb'un öğrenme stili modelinin genel özellikleri Şekil 1'de somutlaştırılarak gösterilmiştir.

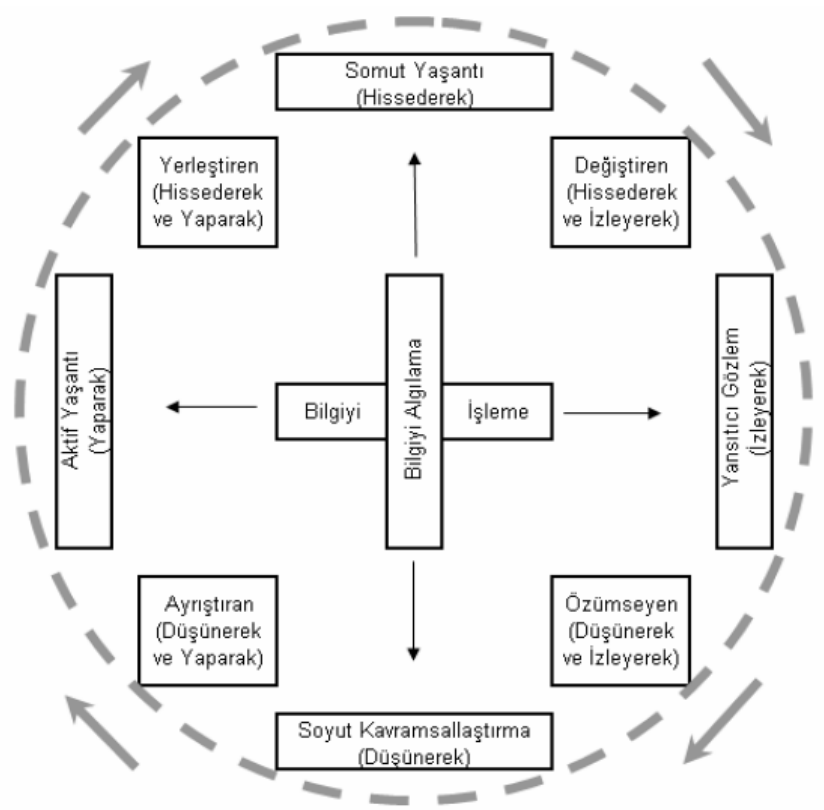

Şekil 1. Kolb'un Öğrenme Modeline Dayalı Öğrenme Stilleri (Kolb, 1984).

\section{Kolb'un Dört Aşamalı Öğrenme Döngüsü}

Kolb'un dört aşamalı öğrenme döngüsünün genel özellikleri aşağıda yer almaktadır (Kolb, 1984 ve 1999; Akt: Evin Gencel, 2006; Yetim, 2008):

Somut yaşantı (deneyim): Yaşantısal öğrenenler; kendilerini direk olarak yeni deneyimler içine dâhil ederek döngünün ilk aşamasına yani "somut yaşantı"ya girerler. Somut deneyimi yüksek kişiler, "empatik" ve "insan yönelimli" olma eğilimindedirler. Onlar, her durumda deneme yapmayı tercih ederler. Kendilerini ilgilendiren ve kendilerini nasıl etkileyeceğini 
anladıkları özel veya spesifik durumlarda en iyi şekilde öğrenirler. Bu kişiler, akranlarına karşı daha fazla yönelme eğilimindeyken öğrenme ortamlarındaki otoriteye karşı daha az yönelimli olma eğilimindedirler. Bu kişiler, öğrenmeleriyle ilgili geri bildirim aldıkları ve öğrenme ortamlarında tartışmalara katıldıkları zaman en iyi şekilde öğrenirler. Onların karakteristik sorusu "niçin?" dir. Bu öğrencilerin etkili olabilmesi için öğretmenin güdüleyici olarak işlev görmesi gerekir. Somut deneyimlerle öğrenmeyi tercih eden öğrenciler, konuları yaşamla ilişkilendirir, öğrenme konusu ve içeriğiyle ilgili özel durumlara, örneklere ve olayların içerisinde yer almaya ihtiyaç duyarlar.

Yansıtıcı gözlem (izleme): Yansitıcı gözlem aşamasının planı, somut deneyimde yapılan etkinlik ve eylemlerin devamı niteliğindedir. Somut deneyim aşamasında sergilenen çeşitli durumların analizi ve varsa sorunla ilgili çözümlerin bulunmaya çalışıldığı aşama olarak da görülmektedir. Kolb'a göre yansıtıcı gözlem öğrenme yolunu benimseyen bireyler, olay ve olguların temelindeki düşünceyi anlama çabasındadırlar. Bu aşamada, konuyla ilgili görüş ve düşünceleri yansıtma, gerçeklerin meydana gelme şeklini sorgulama ve belli kararlara varma söz konusudur. Diğerlerini gözlemledikçe ve kendilerinin ve diğerlerinin deneyimleri hakkında derinlemesine düşünen kişiler "yansıtıcı gözlem" safhasına geçerler. Yansıtıcı gözlemi yüksek kişiler, tarafsız, deneysel ve yansıtıcı bir öğrenme yaklaşımına sahiptirler. Verdikleri kararlar dikkatli gözlem yapmalarına bağlıdır. İyi tanımlanmış görevlerde, aktif olarak çalışma fırsatına sahip olduklarında, deneme-yanılma yöntemini kullandıkları öğrenme çevresinde en iyi şeklide öğrenirler. Nesnel bir gözlemci olarak rol aldıkları bir öğrenme ortamında daha iyi şekilde öğrenirler. Temel sorular "neden, niçin ve nasıl"dır. Etkili olabilmeleri için öğretmenin rehber ve geri bildirim sağlayan bir kişi olarak işlev görmesi gerekir.

Soyut kavramsallaştırma (düşünme): Kendi gözlem ve algılarını mantıksal kuramlarla özümseyerek üçüncü aşama olan "soyut kavramsallaştırma"ya geçerler. Soyut kavramsallaştırması yüksek kişiler, mantıksal düşünme ve rasyonel değerlendirmeye bağlanan öğrenmeye yönelik analitik ve kavramsal bir yaklaşıma sahiptirler. Bu insanlar, nesnelere ve sembollere karşı daha fazla eğilim gösterirlerken diğer insanlara karşı daha az 
eğilimlidirler. Onlar, kuram ve sistematik analizi vurgulayan ve otoritenin etkili olduğu öğrenme ortamlarında daha iyi öğrenirler. Simülasyon, uygulama ve alıştırma gibi düzenlenmeyen öğrenme durumlarında iyi öğrenemez ve kendilerini engellenmiş hissedebilirler. Onların, karakteristik sorusu "nedir?" Verimli olmaları için öğretmenin bir uzman olarak işlev görmesi gerekir. Soyut kavramsallaştırma öğrenme yolunu tercih eden öğrenciler, bilgi ve düşüncelerin mantıksal olarak yapılandırılarak sunulmasına ihtiyaç duymaktadır. Diğer bir deyişle, bu aşama öğrenme konusuna ilişkin kuramsal bilginin belli bir düzen içerisinde sunulmasını gerektirmektedir. Dolayısıyla öğretmenin yaptığı özetler ve anlatımlar uygun bulunmaktadır. Öte yandan öğrencilere bireysel çalışma imkânı sunulması, okuyarak öğrenmeleri için uygun ortam oluşturulması önerilmektedir.

Aktif yaşantı (deneyim): Karar verme ve problem çözmede kavramları kullanılarak öğrenme döngüsünün son aşaması olan "aktif yaşantı" yı (deneyim) sergilenir. Aktif deneyimi yüksek bireyler, yoğun bir şekilde deneyimle bağlanan "yapma" ve "aktif" yönelimli bir öğrenme gösterirler. Bu kişiler, projeler, uygulamalı ev ödevleri veya küçük grup tartışma/an gibi durumlarda en iyi şekilde öğrenirler. Kendilerine sürekli ders anlatılması şeklindeki pasif öğrenme durumlarından hoşlanmazlar. Bu kişiler, dışa dönüktürler ve karakteristik soruları "ya... ise?"dir. Bu kişilerin etkili olabilmesi için öğretmenin açık uçlu sorular sorması ve daha sonra kenara çekilip, öğrencilerin kendi kendilerine konuları keşfetmelerini sağlayacak öğretim stratejilerini ve yöntemlerini (örneğin, buluş yoluyla öğretim stratejisi, probleme dayalı öğrenme... vb. ) kullanarak ders işlemesi gerekir. $\mathrm{Bu}$ aşamada öğrencilerin uygulamalarla öğrenmelerine ve öğrendiklerini uygulamalarına fırsat tanınmalıdır. Dinlemek ve gözlem yapmak yerine etkinliğe katılmak önem kazanmaktadır.

Tablo 3'te Kolb öğrenme stili modelinde yer alan dört öğrenme biçiminin güçlü öğrenme yönleri, tercih edilen ortamları, öğretim etkinlikleri, özellikleri, öğretme şekli ve etkinlik tercihleri yer almaktadır. 
Tablo 3. Kolb Öğrenme Biçimlerinin Güçlü Olan Öğrenme Yönleri ve Tercih Edilen Ortamlarn

\begin{tabular}{|c|c|c|}
\hline Öğrenme Biçimleri & Güçlü Olan Öğrenme Yönleri & $\begin{array}{l}\text { Tercih Edilen } \\
\text { Ortamlar }\end{array}$ \\
\hline Somut yaşantı & $\begin{array}{l}\text { Sezgileri ile öğrenirler. } \\
\text { Hislerine duyarlıdırlar. } \\
\text { İnsanlarla ilişki kurarlar. } \\
\text { Özel deneyimlerden öğrenirler. }\end{array}$ & $\begin{array}{l}\text { Kişisel tavsiyeler. } \\
\text { Akranlarından gelen dönütler } \\
\text { ve tartışmalar. } \\
\text { Öğretmen rehber, yardımcıdır. } \\
\text { Yeni deneyimlerden öğrenir; } \\
\text { oyunlar, rol oynama gibi. }\end{array}$ \\
\hline Yansitıcı gözlem & $\begin{array}{l}\text { İçedönüktürler. } \\
\text { Gözlem yaparlar. } \\
\text { Algıları ile öğrenirler. } \\
\text { Karar vermeden önce dikkatle } \\
\text { Farklı bakış açlarına göre bir } \\
\text { şeyleri incelerler. }\end{array}$ & $\begin{array}{l}\text { Ders notları. } \\
\text { Aktif gözlemci rolündedirler. } \\
\text { Öğgretmen rehber ve görev yö- } \\
\text { neticisidir. } \\
\text { Farklı bakış açlarından bilgi } \\
\text { sağlamaya çalışırlar. }\end{array}$ \\
\hline $\begin{array}{l}\text { Soyut } \\
\text { kavramsallaştırma }\end{array}$ & $\begin{array}{l}\text { Sistematik planlama. } \\
\text { Düşünerek öğrenme. } \\
\text { Tümdengelim düşünme. } \\
\text { Fikirlerin mantıksal analizleri. }\end{array}$ & $\begin{array}{l}\text { Teorik okuma. } \\
\text { Tek başına çalışma. } \\
\text { Öğretmen bilginin sunucusu. } \\
\text { Açık iyi yapılandırılmış fikir } \\
\text { sunumları. }\end{array}$ \\
\hline Aktif yaşantı & $\begin{array}{l}\text { Risk alma. } \\
\text { Dişadönüklük. } \\
\text { Yaparak öğrenme. } \\
\text { Yaparak öğrenme becerisi. }\end{array}$ & $\begin{array}{l}\text { Küçük grup tartışmaları. } \\
\text { Dönüt alma ve uygulama } \\
\text { imkânı. } \\
\text { Projeler ve kişisel öğrenme ak- } \\
\text { tiviteleri. } \\
\text { Öğretmen bir şeyin nasıl yapı- } \\
\text { lacağını söyleyen kişi. }\end{array}$ \\
\hline
\end{tabular}

Kaynak: Pierce, 2000'den uyarlayan Kılıç, 2002.

\section{Kolb'un Dört Farklı Öğrenme Stili}

Kolb'un modelinde yer alan ayrıştıran, değiştiren, özümseyen ve yerleştiren öğrenme stillerinin ve bu stillere sahip bireylerin özellikleri (Ekici, 2003; Karademir ve Tezel, 2010) ile bir öğretmenin sınıf ortamında ve öğretim sürecinde neler yapabileceğine dair öneriler şu şekilde belirtilmektedir (Pritchard, 2009: Nilson, 2010; Akt: Arslangilay, 2015; Kolb 1984; 1999; Akt: Evin Gencel, 2007):

Değiştiren öğrenme stili: Somut yaşantı ve yansıtıcı gözlem öğrenme biçimlerini içerir. Bu öğrenme stiline sahip bireylerin en önemli özelliği dü- 
şünme yeteneği gelişmiş olup değer ve anlamların farkındadırlar. Değiştiren, somut durumları farklı açılardan gözden geçiren ve ilişkileri anlamlı bir şekilde düzenleyen kişilerdir. Öğrenme sürecinde sabırlı, nesnel, dikkatli yargılarda bulunan fakat sadece bir eylemde bulunmayanlardir. Kendi düşünce ve duygularını göz önüne alarak düşünceleri biçimlendirirler. Psikoloji, edebiyat, sosyal çalışmalar, gazetecilik, sanat, tiyatro gibi alanlardaki meslekleri öncelikli olarak tercih ederler. Sınıf ortamında ve öğretim sürecinde neler yapabileceğine dair öneriler şöyle ifade edilebilir. "Nasıl?" sorusunu kullanan, problem çözerek ve teknik görevler yaparak öğrenmeyi tercih eden bu öğrenciler için öğretmen rahatlıkla yanlış yapabilecekleri bir ortamda deneme yanılma yoluyla öğrenmelerini sağlayabilmelidir. Gösteri yöntemi de bu öğrencilerin zevkle öğretime katılacakları yöntemler arasındadır. Ayrıca öğretmen bu tür öğrenciler için araştırmaya yönlendiren deneyler yaptırabilir. Alan gezileri, örnek olaylar ve simülasyonlar bu öğrencilerin derse aktif katılımını sağlayacak yöntemlerden bazılarıdır. Değiştiren öğrenme stiline sahip olan öğrenciler, öğrenme sürecinde sabırlıdır, dikkatlidir ve farklı fikirlerin üretildiği durumlar üzerinde odaklanmayı severler.

Özümseyen öğrenme stili: En belirgin özelliği kavramsal modelleri oluşturma olan özümseyen öğrenme stili soyut kavramsallaştırma ve yansitıcı gözlem öğrenme biçimini kapsar. Bir şeyler öğrenirken soyut kavramlar ve fikirler üzerinde odaklanırlar. Bu öğrenme stiline sahip kişilerin, geniş ve kapsamlı bilgileri mantıksal bir bütün haline getirmede oldukça başarılı oldukları belirtilmektedir. Özümseyen öğrenme stiline sahip olan bireyler biyoloji, eğitim, öğretmenlik, matematik, sosyoloji, hukuk, kütüphanecilik gibi meslekleri tercih etmektedirler. Sınıf ortamında ve öğretim sürecinde neler yapabileceğine dair öneriler şu şekilde özetlenebilir. "Ne?" sorusunu kullanan, bilgileri mantıki bir sıraya koyarak ve yansitıc1 gözlem kullanarak öğrenmeyi tercih eden bu bireyler için öğretmenlerin uygulayacağı mantıksal ve olgusal dersler etkili olacaktır. Kendi başlarına etkin bir şekilde okuyan ve dinleyen bu öğrenciler için ders kitaplarından okuma ödevleri verilebilir, bağımsız veri toplamaları, analiz araştırmaları yapmaları ya da kütüphanede araştırma yapmaları sağlanabilir. Bu tür öğrenciler için öğretmen, gösteri yöntemini kullanabilir, problem çözme yöntemlerini canlı olarak ya da video ile gösterebilir. Soyut kavramlar ve 
fikirler üzerine odaklanmalarının yanı sıra, özümseme öğrenme stiline sahip olan öğrenciler öğretmeni temel bilgi kaynağı olarak kabul eder, bilgiyi öğretmen ve uzman kişilerden öğrenmeye öncelik verirler. Bundan dolayı geleneksel öğrenme ortamlarında daha fazla başarı sergiledikleri belirtilmektedir.

Ayrıştıran öğrenme stili: Soyut kavramsallaştırma ve aktif yaşantı (deneyim) biçimlerini kapsar. Problem çözme, karar verme, fikirlerin mantıksal analizi ve sistematik planlama bu öğrenme stiline sahip kişilerin belli başlı özelikleridir. Tümdengelimci akıl yürütmeye sahip olan bu kişilerin, mantıksal çözümleme, doğru karar verme ve problem çözme becerilerinin gelişmiş olduğu, sosyal ve kişiler arası etkinlikler yerine teknik konularla ilgilenmeyi tercih ettikleri vurgulanmaktadır. Bu öğrenme stilinde sahip olan bireyler için yaparak öğrenme önemlidir ve bu bireyler tıp, mühendislik, ekonomi, bilgisayar bilimleri gibi teknoloji kullanmaya ağırlık veren meslekleri seçerler. Sınıf ortamında ve öğretim sürecinde neler yapabileceğine dair önerilere kısaca şöyle yer verilebilir. "Neden?" sorusunu kullanan bu tür öğrencileri için öğretmenler; her tür tartışma yöntemini (tüm sınıf, küçük gruplar ya da birebir) ve grup projelerini kullanabilir. Gözlem, beyin fırtınası ve bilgiyi bir araya getirmek yoluyla öğrenmeyi tercih eden ve hayal güçleri kuvvetli olan bu öğrenciler için öğretmen, duygusal etkisi olan dersler ve hikâyeler ile interaktif dersler yapabilir, yazılı sınavlar yapabilir ve yazma görevleri verebilir. Bu tür öğrencilerin ilgisini çekecek ve onların derse odaklanmasını sağlayacak diğer öğretim yöntemleri: alan gezileri, rol oynama, simülasyon, örnek olay, problem temelli öğrenme gibi deneysel yöntemler olarak sıralanabilir. Ayrıştıran öğrenme stiline sahip olan öğrencilerin, uygulamaya dönük çalışmalar yapmalarının gerekliliği ve konulara çeşitli bakış açılarıyla yaklaşma yeteneklerini artıracak eğitim etkinlikleri yaşamalarının gerekliliği vurgulanmaktadır.

Yerleştiren öğrenme stili: Somut yaşantı ve aktif yaşantı öğrenme biçimini kapsar. Bu öğrenme stiline sahip kişilerin planlama yapma; kararları yürütme ve yeni deneyimler içinde yer alma belli başlı özellikleridir. Öğrenme sürecinde bireyler açık fikirli ve değişmelere kolayca uyum sağlarlar. Aynı zamanda liderlik özelliğine sahip olan bu öğrenciler, öğrenme 
durumlarında teknik çözümlemeler yerine, bireyler arası ilişkilerden yararlanmayı ve başka bireylerin de bilgilerine başvurmayı önemserler. Meraklı ve araştırmacı olarak nitelendirilen yerleştirme stilindeki öğrenciler, genellikle girişkenlik, esneklik ve açık görüşlülük özellikleri ile ön plana çımaktadır. Bu öğrenme stiline sahip olan bireyler eğitim yönetimi, kamu yönetimi, pazarlamacılık, yönetim, bankacılık gibi meslekleri tercih etmektedirler. Sınıf ortamında ve öğretim sürecinde şu hususlara dikkat edilebilir. "Ya ... ise?" sorusunu kullanan, problem çözme durumlarında yeni materyalleri uyguladıklarında iyi öğrenen bu tür öğrenciler için öğretmenler, araştırma yönlendirmeli etkinlikler kullanabilir. Aktif öğrenen bu öğrenciler için tartışmalar ve beyin fırtınası uygun yöntemler sayılabilir. İnsan odaklı olan “yerleştiren” öğrenciler, grup çalışmaları ve projelerden zevk alırlar. Yerleştiren öğrenme stiline sahip öğrencilerin, soyut kavramsallaştırma ve yansıtıcı gözlem öğrenme yollarına uygun etkinliklerle; çalışma sonuçlarıyla ilgili bilgiye ulaşma ve analiz etme, öğrenme sürecinde zihinsel olarak daha aktif rol üstlenme; öğrenme sürecinde diğer öğrencilerin deneme-yanılmalarını gözlemleyerek çıkarımlarda bulunma gibi durumlarda daha başarılı olacakları ifade edilmektedir.

\section{Honey \& Mumford'un Öğrenme Stili Modeli}

Bu öğrenme stili modeli, Kolb"un öğrenme stilleri sınıflamasını temel alarak geliştirdikleri modelde herhangi bir öğrenme görevini yeterli bir şekilde tamamlayabilmek için belirledikleri dört farklı stilden birinin benimsenmesi gerektiğini belirtmişlerdir. Bu stiller şunlardır:

- Eylemciler,

- Yansiticilar,

- Kuramcilar,

- Pragmatistler.

Honey ve Mumford'un aşamaları ve stilleri, Kolb'un öğrenme modelindeki şu aşamalara karşılık gelir: Eylemci-yerleştiren; yansıtıcı-değiştiren; kuramc1-özümseyen; pragmatist-ayrıştıran (Yetim, 2008). Honey ve Mumford öğrenme stili modeline ilgili öğrenme stiline sahip öğrencilerin genel özellikleri, bu modele göre bir öğretmenin sınıf ortamında ve öğretim sürecinde neler yapabileceğine dair öneriler ile bu öğrenme stillerine 
sahip olan öğrencilerin en iyi öğrendikleri durumlara aşağıda detaylı olarak yer verilmiştir.

Eylemciler: Yeni deneyimlere açıktırlar, girişken ve açık görüşlüdürler. Yönetilmekten ve kurallardan hoşlanmazlar. Olayların merkezinde olmayı severler. Öncelikle eylemde bulunur, sonuçları daha sonra düşünürler. Uğraştıkları işten sıkıldıkları anda yeni deneyimler ararlar. Karşılaştıkları sorunları beyin fırtınası tekniği ile çözerler (Honey ve Mumford, 1995; Akt: Gündoğan Çögenli, 2011). Bu öğrenme stiline sahip olan öğrenciler okuyarak ya da dinleyerek değil yaparak öğrenmeyi tercih ederler. Denemeyi seven ve yeniliğe açık olan bu öğrencileri için öğretmenler; ekip çalışması, oyunlar ve simülasyonlar, beyin fırtınası, yapılandırılmamış tartışmalar ve proje çalışması gibi yöntemler kullanabilirler. Bu öğrenciler için dışadönük etkinliklerden biri olan sunum yapmak ve problem temelli öğrenme yöntemi kullanmak öğretmenin seçebileceği etkinlikler arasındadır. Bu tür öğrenciler yaparak öğrenmeyi sevdikleri için anlatım ağırlıklı ders dinlemek gibi pasif öğrenme onlar için uygun değildir. Uygulama imkânlarının olmadığı kavramları çalıştırmak da bu öğrencilerin öğretim sürecinde zorluk yaşamalarına neden olacaktır (Mobbs, 2003; Fewings, 2015; Pritchard, 2009; ELT, 2003; Akt: Arslangilay, 2015). Bir görevi yerine getirdikleri ve bir faaliyette etkin olarak rol aldıkları zaman en iyi şekilde öğrenen eylemcilerin en iyi öğrendikleri durum ve zamanlar şöyledir (Yetim, 2008):

- Heyecanlandıkları zaman,

- Dikkatleri ve ilgileri çekildiği zaman,

- Öğrenmelerinde serbest kaldıkları zaman,

- Tartışmayı kendileri düzenledikleri zaman,

- Öğrenme etkinliklerinin yönlendirdikleri zaman,

- Yeni tecrübeler, olanaklar ve problemler olduğu zaman.

Yansıtıcılar: Bir durumu derinlemesine düşünerek ve farklı açlardan gözlemleyerek anlamayı tercih ederler. Öğrenirken çeşitli kaynaklardan veri toplarlar ve sonuca varmadan önce etraflıca düşünürler. Bir işle uğraşırken dikkatli davranırlar. Diğer insanları gözlemlemekten hoşlanırlar (Honey \& Mumford, 1995; Akt: Gündoğan Çögenli, 2011). Bu öğrenme stiline sahip öğrenciler daha çok gözlemlemeyi ve dikkatlice düşünüp karar 
vermeden önce bilgi toplamayı tercih ettikleri için öğretmen bu öğrenciler için beyinsel etkinlikler, video izlemek gibi pasif durumları uygulayabilir. Genellikle kendilerine çok fazla güvenemeyen ve sınıf içi etkinliklere direk katılımdan çekinen bu öğrenciler için rol oynama gibi dışadönük etkinlikler seçilmemelidir. Ayrıca öğretmen, hızlı karar verme konusunda daha zayıf olan bu öğrencilerine zamanla kısıtlanmış etkinlikler uygulamay1 tercih etmemelidir (Mobbs, 2003; Fewings, 2015; Pritchard, 2009; ELT, 2003; Akt: Arslangilay, 2015). Bir şeyin nasıl meydana geldiğini gözleyebildikleri zaman iyi şekilde öğrenen yansitıcı öğrenenlerin en iyi öğrendikleri durum ve zamanlar şunlardır (Yetim, 2008):

- Geri planda rol üstlendikleri zaman,

- Öğrenme deneyimlerini yapısallaştırdıkları zaman,

- Düşünmeleri ve düşünmelerini yansıtmaları için süre tanındığı zaman,

- Faaliyet ve etkinlikleri gözlemlemeye ve düşünmeye yönlendirildikleri zaman.

Kuramcılar: Problem çözerken mantıklı ve aşamalı bir yol izlerler. Farklı kavramları düzenli bir biçimde mantıksal sırada özümserler. Analiz ve sentez yapabilirler. Varsayımlar, ilkeler, kuramlar ve modeller ile ilgilenirler. Akla uygun ve mantıklı bilgiyi kabul ederler. Onlara göre bir şey mantıklı ise iyidir. Sıkça şu soruları sorarlar: "Anlam ifade ediyor mu?", "Temel varsayımlar nelerdir?" (Honey ve Mumford, 1995; Akt: Gündoğan Çögenli, 2011).

Bu tür öğrenme stiline sahip olan öğrenciler daha çok mantıklı ve akılcı olduklarından öğretmenlerinin onlara sunacağı mantıklı fikirleri okumak ya da dinlemekten hoşlanırlar. Belli amaçları olan yapılandırılmış durumlar bu öğrencileri mutlu edecektir. Düzensiz ve belirsiz ortamlarda motivasyon seviyeleri düşen bu öğrenciler için öğretmen açlk uçlu sorular sormamalı, ayrıntılı inceleme gerektirmeyen fikirler üzerinde çalışma yaptırmayı tercih etmemelidir (Mobbs, 2003; Fewings, 2015; Pritchard, 2009; ELT, 2003; Akt: Arslangilay, 2015). Geniş bir resimdeki küçük bir parçanın nasıl oluştuğunu anladıkları zaman en iyi şekilde öğrenen kuramcı öğrenenlerin en iyi öğrendikleri durum ve zamanlar şöyle izah edilebilir (Yetim, 2008): 
- İncelemeleri derinlemesine yaptıkları zaman,

- Öğrenme akılcı ve mantıksal görüldüğü zaman,

- Öğrenme kesin ve açık amaçlarla yapısallaştırıldığı zaman,

- Öğrenmeyi bir model içinde kendileri düzenledikleri zaman,

- Durum ve görüşleri yöntemlerle araştırmak için zamanları olduğu zaman,

- Sırasıyla düşünme, analiz etme ve en son genellemeye ulaştıkları zaman.

Pragmatistler (faydacılar): Kuram ve fikirlerin, uygulamada işe yarad1ğını görmek isterler. Problem çözerken pratik kararlar verebilirler. Yeni fikirler üretmeyi ve deneyim kazanmayı tercih ederler. Onlara göre her zaman daha iyi bir yol vardır (Honey \& Mumford, 1995; Akt: Gündoğan Çögenli, 2011). Yeni fikirler bulmak ve kullanmakta başarılı olan bu öğrenme stiline sahip öğrenciler, bir şeyleri denemeyi ve uygulamada görmeyi tercih ederler. Öğretmen onları pratik avantajları olan beceri ve teknikler üzerinde çalıştırmalıdır. Bu öğrenciler için uygulamalı gösteri, simülasyon yöntemi kullanılabilir. Öğretmenlerin dikkat etmesi gereken bir nokta da net bir uygulama ya da yönerge olmadan başarılı bir şekilde çalışma yapamayacak bu öğrencilerini uygulama imkanı bulunmayan kavramlarla çalıştırmamasıdır. Bu tür öğrenciler için uygulayamadıkları ve gerçeklikten uzak fikirler ve hayal dünyası öğrenmede zorluk teşkil edecektir (Mobbs, 2003; Fewings, 2015; Pritchard, 2009; ELT, 2003; Akt: Arslangilay, 2015). Öğrenmeleri için bir iş üzerinde kendilerine uygulama fırsatı sunulduğunda en iyi şekilde öğrenen pragmatistlerin iyi öğrendikleri durum ve zamanlar şöyledir (Yetim, 2008):

- Bir model ya da kuramı uygulama şansı oldukları zaman,

- Öğrendiklerini uygulama fırsatı verildiği ve pratik yaptıkları zaman.

\section{MAT Öğrenme Stilleri Modeli}

McCarthy'nin altı yıl süren çalışması neticesinde sınıflandırdığı öğrenme stilleri bazı araştırmacıların (Jung, Lawrance, Simon ve Byram, Merril, Hunt, Kolb) bulgularıyla benzerdir. McCarthy, öğrenme stillerini; birinci 
tip öğrenenler (imgesel), ikinci tip öğrenenler (analitik), üçüncü tip öğrenenler (sağduyulu), dördüncü tip öğrenenler (dinamik) olarak dört kategoride ele almıştır.

McCarthy (1987)'ye göre bu öğrenme stillerinin her birisi bir çeyrektedir ve bu çeyrekte yer alan birey kendisine uygun biçimde öğretim yapıldığında kolayca ve daha fazla başarılı olmaktadır (Peker, Mirasyedioğlu ve Yalın, 2003). 4MAT, sekiz aşamalı ardışık bir modeldir. İki teorik yapıya dayanmaktadır: Kolb öğrenme stilleri modeli ve beyin yarıüreleri kavramı. McCarthy her bir eğitim ünitesi için aktiviteler düzenlenirken sol beyin yarıküresinin olduğu kadar sağ beyin yarıküresinin de hesaba katılması gerektiğini düşünmektedir. Sekiz aşamalı model Kolb’ün dört çeyreğinin her birin hem sağ hem de sol beyin yarıküreleri ile etkileşime girmesiyle oluşturulmuştur (Ural-Alşan, 2009). McCarthy (2000) bireylerin bilgiyi farklı şekillerde algıladıklarını ve işlediklerini vurgulamaktadır. Bireyler bilgiyi somut yaşantı ve soyut kavramsallaştırma yetenekleri yoluyla algılarlar. McCarty'e göre, bazı bireyler, yeni öğrenme durumlarında, kendi doğrudan yaşantılarına dayalı olan yollarla hissederek ve sezerek, bazıları da hızlı bir şekilde soyut kavramsallaştırmaya geçerek düşünerek bilgiyi algılarlar (Demirkaya, 2003). Bilgi işlemede, aktif yaşantı ve yansıtıcı gözlem yeteneklerinin önemi artmıştır. Bazı bireyler bilgiyi izleyerek işlerken, bazıları da yaparak, uygulayarak işlerler. McCarthy, deneysel çalışmalar sonucunda elde ettiği bilgiler sonucunda öğrencileri dört kategoriye ayırmış olup bu kategoriler ve özelliklerine aşağıda yer verilmiştir (Akdeniz, 2007; Demirkaya, Mutlu ve Uşak, 2003; Peker, Mirasyedioğlu ve Yalın, 2003).

İmgesel öğrenenler: 4MAT öğretim modelinde, birinci çeyrek imgesel öğrenenler için daha uygun olmasına rağmen öğrencilerin tamamı öğrenme döngüsünde yer alan bütün çeyreklerin öğrenme sürecine uygun şekilde öğrenirler. İmgesel öğrenenlerin temel sorusu "niçin?" sorusudur. Hissederek ve izleyerek öğrenmeyi tercih eden bu öğrenciler, birinci çeyrekte yer alırlar. Yaratıcı öğrenciler yaşadıkları deneyimleri kendi benlikleriyle bütünleştirirler, anlam ararlar, en iyi dinleyerek ve paylaşarak öğrenirler. Birinci tip öğreniciler, bilgiyi somut olarak almakta ve yansıtıcı bir şekilde işlemektedirler. Bu gruptaki öğrencilerin güçlü yanları; yenilikçilik, güçlü hayal gücü ve fikir alışverişi yapmalarıdır. Birinci tip öğrenciler en iyi 
grup tartı̧̧malarına, filmlere, tartı̧̧malarla yapılan kısa ders anlatımlarına, işitsel ve görsel deneyimlere cevap verirler. Anlamı ve açıklığı araştırırlar. Yaşantıları doğrudan ve birçok görüş açısından inceleme konusunda oldukça başarılıdırlar.

Analitik öğrenenler: İzleyerek ve düşünerek öğrenmeyi tercih eden bu öğrenciler ikinci çeyrekte yer alırlar. Bu çeyreğe en uygun olanlar analitik öğrenenlerdir. Ancak 4MAT modelinde öğrencilerin hepsi bu süreçle öğrenmeye devam edebilirler. Ardışı öğrenmeye önem verirler, süreklilik ararlar, kabul edilen bilgi ne ise onu öğrenmeyi isterler, en iyi geleneksel yöntemlerle öğrenirler. İçe dönük olan analitik öğrenenler anlamak için zihinsel yeteneklerine güvenirler. Bu öğrenciler öğrendiklerinin "ne?" olduğunu bilmek isterler. Öğrendikleri bilgilerin uzmanlarca onaylanmış veya kanıtlanmış bilgiler olmasını tercih ederler. Gözlemlerini deneyim ve bilgileriyle bütünleştirerek kuramlar tasarlar ve uzmanların ne düşündüklerini bilme ihtiyacını duyarlar. Bu tip öğreniciler, bilgiyi soyut olarak almakta ve yansıtıcı bir şekilde işlemektedirler. İkinci tip öğrenciler yoğun okuma ödevlerini, dersleri, işitsel kayıtları ve düşünme oturumlarını tercih ederler.

Să̆duyulu öğrenenler: Kavramlar yoluyla düşünerek ve kendileri için bir şeyler deneyerek, yaparak öğrenmeyi tercih eden bu öğrenciler, üçüncü çeyrekte yer alırlar. Bu çeyrekte öğrenilen kavramların pratiği yapılır ve öğretim bireyselleştirilir. Bu çeyrek sağduyulu öğrenenler için en uygun yerdir. Soyut kavramsallaştırmadan aktif yaşantıyla bir öğrenme süreci gerçekleştirilir. Teori ve uygulamayı birleştirirler, sağduyu ve deneme ile fikirleri test ederler, bir şeyin neden ve nasıl olduğunu öğrenmeyi isterler. Üçüncü gruptakiler, bilgiyi soyut olarak almakta ve aktif olarak işlemektedirler. Bu tür öğrenenler karşılaştıkları şeyin kullanışlıı̆̆ğını değerlendirir, kendi yaşantılarıyla ve düşünerek öğrenirler. Faydaya ve sonuca ulaşmaya önem verirler ve teorileri test ederek öğrenirler. Üçüncü tip öğrenciler çalışma kitaplarına, kılavuzlara, gösterilere, yaparak-yaşayarak öğrenme aktivitelerine ve alan gezilerine ihtiyaç duyarlar. Bu gruptaki öğrenciler, deney yaparlar ve yaptıkları deneyler üzerinde fikir yürütürler. Nesnelerin ve formüllerin nasıl çalıştı̆̆ını bilmek isterler. 
Dinamik öğrenenler: Dördüncü çeyrekte deneyimi bütünleştirme ve uygulama ön plandadır. Dinamik öğrenenler için en uygun yer olan bu çeyrekte, öğrenciler bir şeyler yapmayla ilgilenirler. Aktif yaşantıdan somut yaşantıya oradan da yaparak öğrenmeden sezerek öğrenmeye bir öğrenme süreci oluşur. Burada öğrencilerin bilgiyi kendi kendilerine öğretmelerine ve öğrendikleri bilgileri diğer öğrencilerle paylaşmalarına izin verilir. Bireysel olarak yapılan deneyler ve yaşantı dinamik öğrenenlerin hoşuna gider. Öğrenciler hissederek ve yaparak öğrenmeyi tercih etmektedir. Deneyim ve onun uygulamalarını birleştirirler, kendi kendine keşif yapmaktan hoşlanırlar, yargılama ve hata yaklaşımlarını severler. Dördüncü tip öğrenciler, bilgiyi somut olarak alırlar ve aktif olarak işlerler. Deneme yanılma yoluyla öğrenirler. Dördüncü tip öğrenciler, oyunlarla, simulasyonlarla, bağımsız çalışma ile problem çözme ve özel okuma ödevleriyle en iyi öğrenirler. Bu gruptaki öğrenciler değişikliklere karşı uyumludurlar ve diğer insanlarla kolayca iletişim kurabilirler.

4MAT sistemi iki temele dayanmaktadır. Birincisi, öğrencilerin ana öğrenme stillerine ve yarımküre işleme tercihlerine sahip olduklarıdır. İkincisi, öğretmenler sistematik bir çerçevede bu tercihleri dikkate alarak çoklu öğretim stratejileri kullandıklarında öğretim ve öğrenmenin gelişmesidir. Sağ-mod tercihi olan öğrenciler yaratıcı ve dinamik öğreniciler olarak sınıflandırılmaktadır (Beck, 2001; Akt: Ural Alşan, 2009). Çünkü bu gruptaki öğrenciler, genellikle diğerleriyle bir şeyler paylaşmayı ve etkileşime geçmeyi tercih etmektedirler. Bu öğrenciler düşünüp tartışılan ve birliğe dayalı öğretim kategorilerine meyillidirler. Öğretim stratejilerinin edimsel kategorisi sağ-mod öğreniciler için uygun görünmektedir, çünkü bu öğrenciler hareket etmeyi ve kendilerini yaratıcı bir şekilde ifade etmeyi tercih ederler (Ural Alşan, 2009).

Tablo 4'ün alt yarısında belirtildiği gibi sol modlu öğreniciler analitik ve sağduyulu öğreniciler olarak sınıflandırılmaktadırlar. Bu öğrenciler, fikirleri ve detayları bağımsız olarak işlemeyi tercih ederler, açılayıcı ve bireysel öğretim stratejilerine yatkındırlar. Sıralı ve sistematik bir ilerlemeyi gerektirdiğinden sorgulayıcı öğretim stratejileri de bu öğrenicilere uygundur. 4MAT sistemin ikinci dayanağı, her iki yarımkürenin kullanımını cesaretlendiren çeşitli öğretim stratejilerini birleştirmeleri ve uygulamaları konusunda cesaretlendirmesidir. Sağ ve sol modların gerçeği alg1lamaları birbirinden farklıdır. Ancak aynı zamanda her iki mod birbirinin 
tamamlayıcısıdır. Eğer beynin tamamının çalışmasında her iki yarımküre de eşit olarak önemliyse, öğretmenlerin her iki yarımküreyi uyaracak stratejileri birleştirmesi gerekmektedir. 4MAT sistem bir halka içerisinde dört öğrenme stiline yönelik eğitim yapılmasını, böylelikle sırasıyla her iki yarımküreye de yönelimini cesaretlendirmektedir (Ural Alşan, 2009).

Tablo 4. 4MAT Sistem Öğrenicilerinin Öğretim Stratejileri Kategorileriyle Eşleştirilmesi

\begin{tabular}{ll}
\hline Sağ-Mod (Yarıküre) Tercihi & \\
\hline Yaratıcı & Düşünen \\
Görsel işleme. & Yuvarlak masa, fish bowl, sihirli halka ve beyin fırtı- \\
Bütünsel anlama. & nası gibi tartışma stratejileri içerir. \\
Yapma ve yansıtma. & Çağrışımlı \\
Tartışma ve paylaşma. & İlgi ve beceri grupları, işbirlikçi öğrenme gibi grup \\
Hayal etme ve yaratma. & stratejileri içerir. \\
Dinamik & \\
Grup etkileşimi. & Edimsel \\
Duyumsal işleme. & Drama, güzel sanatlar, oyun oynama, \\
Esneklik ve değişim. & simulasyonlar gibi eğlenceli ve yaratıcı stratejiler içe- \\
Çeşitli/farklı düşünme. & rir. \\
Yeni fikirler oluşturma. & \\
\hline Sol-Mod (Yarıüre) Tercihi & Açıklayıcı \\
\hline Analitik & Ders anlatımları, yazılı ve sözlü raporlar ve okumalar \\
Sözcük işleme. & gibi açıklayıcı stratejiler içerir. \\
Ardışık düşünme. & \\
Dinleme ve yansıtma. & Araştırıcı \\
Sözel yeteneklere odaklanma. & Problem çözme, sorgulama ve deney yapma gibi tü- \\
Fikirler, gerçekler ve detaylar. & mevarımsal ve sistematik stratejiler içerir. \\
Sağduyu & Bireysel \\
Problem çözme. & Bireyselleştirilmiş stratejiler içerir (bağımsız çalışma, \\
Mantıksal işleme. & uzmanlık ve programlı öğrenme gibi). \\
Yeteneklere odaklı. & \\
Yakınsak düşünme. & \\
Deney yaparak test etme. & \\
\hline Kăm & \\
\hline
\end{tabular}

Kaynak: Beck, 2001'den uyarlayan Ural Alşan, 2009.

\section{Grasha E Riechmann Öğrenme Stili Modeli}

Grasha ve Riechmann öğrenme stillerini pasif, katılımcı, rekabetçi, işbirlikli, bağımlı ve bağımsız olarak altı farklı şekilde sınıflamıştır (Grasha, 996). Bu modelinde yer alan altı öğrenme stilinin genel özellikleri ve bu 
stili tercih eden öğrencilerin özellikleri aşağıda yer almaktadır (Grasha, 1996; Akt: Bahar, 2009).

Rekabetçi öğrenme stili: Rekabetçi öğrenme stilinde olan öğrenenler, s1nıftaki diğer öğrencilerden daha iyi performans sergilemek için daha fazla çaba sarf ederler. Dikkat çekmeyi ve başarılarından dolayı tanınmayı isterler. Bu öğrenme stilindeki bireylerin olumlu yönleri motivasyonları yüksektir, motivasyonlarını devam ettirmeleri, öğrenme için amaçlarının olması, iyi performans göstermek için daha fazla çaba harcamalarıdır. Olumsuz yönleri ise işbirlikli öğrenme yeteneklerinin ve diğer insanları takdir etme yeteneklerinin az olmasıdır. Daha az rekabetçi kişileri sıkar.

İşbirlikli öğrenme stili: İşbirlikli öğrenme stilinde olan bireyler düşüncelerini paylaşmayı ve diğer insanlarla çalışmayı severler. Bu öğrenme stilindeki bireylerin takım hâlinde çalışma yeteneklerinin yüksek olması olumlu yönleri; rekabetçi bireyler kadar iyi hazırlanmama ve onlarla baş edememe, tek başına iyi çalışamama ve diğer bireylere fazla bağımlı olma gibi olumsuz yönleri olabilir.

Pasif-çekingen öğrenme stili: Pasif öğrenme stilinde olan bireyler derse katılımda ve dersin içeriklerini öğrenmede yeteri kadar istekli değildirler. Öğretmen ve diğer öğrencilerle ilişkileri de yeterli düzeyde değildir. Bu öğrenme stilindeki bireylerin olumlu yönleri, yaşantılarını değiştirmede, ciddi adımlar atmada endişe ve risk almadan kaçınma, neşeli işlerle uğraşmayı sevme olarak verilebilir. Zamanlarını neşeli yapabilirler ama üretkenlikleri azdır. Bazı başarısızlıkları hatırlatıldığında performansları düşer ve olumsuz dönütleri harekete geçer. Üretkenlikleri düşüktür, öğretmen ve diğer öğrencilerle ilişkileri azdır.

Katılımcı-paylaşımcı öğrenme stili: Katılımcı öğrenme stilinde olan bireyler sinıfta ve diğer ortamlarda iyi bir vatandaşlık görüntüsü sergilerler. Sınıfa gitmekten ve derslere katılmaktan hoşlanırlar. Öte yandan seçmeli derslerde sorumluluk almak için gönüllüdürler. Bu öğrenme stilindeki bireylerin her dersten olabildiğince deneyim kazanma olumlu yönleri olarak görülürken, bazen kendi gereksinimlerinden daha fazlasını yapmaları 
olumsuz olarak görülmektedir. Diğer öğrencilerin ihtiyaçlarını ve isteklerini kendi ihtiyaçlarının önünde tutarak kendilerini ikinci plana atarlar.

Bağımlı öğrenme stili: Bağımlı öğrenme stilinde olan bireyler ne gerekiyorsa onu öğrenirler ve zihinsel meraklarının çok az kısmını sergilerler. Öğretmenlerini ve arkadaş grubunu bilginin önemli kaynağı olarak görür ve onları ne yapacakları hakkında özel yol göstermeleri için bir otoriter kişi olarak kabul ederler. Endişeleriyle baş edebilirler ve talimatları net olarak alırlar. Bu öğrenme stilindeki bireylere destek sağlandığında meraklarını gidermeleri ve yol göstermeler ile deneyim kazanmaları olumlu yönleri sayılmaktadır. Öte yandan bir öğrenen olarak kendi kendine öğrenme, otoritelerini sergileyici yeteneklerini geliştirmelerinin güç olması ve belirsizliklerle nasıl başa çıkacaklarını öğrenmemeleri olumsuz yönleri olarak görülmektedir. Kısaca kendi kendilerini yönlendirme ve öğrenme becerileri zayıftır. Problemleri çözmede veya belirsizliklerle başa çıkmada zorlanırlar.

Bağımsız öğrenme stili: Bu grupta yer alan bireyler öğrenme yeteneklerinden memnundur ve kendi kendilerine düşünmeden hoşlanırlar. Önemli gördükleri ders konularını öğrenmeyi tercih ederler. Öğrenme sürecinde diğer öğrencilerle çalışmaktansa yalnız çalışmaya öncelik verirler. Bağımsız öğrenme stilindeki bireylerin kendi kendilerine öğrenme ve girişimcilik yeteneklerini geliştirmeleri ve kendi kendini yönlendirerek geliştirmeleri olumlu yönleri olarak görülmektedir. Birlikte çalışma yeteneklerinin düşük olması, başkalarına danışmada veya yardıma ihtiyaçları olduğunda diğerlerine sorma yeteneklerinin olmaması, diğer öğrencilerle görüş alışverişinde bulunmakta, soru sormakta ya da onlardan yardım isteme konusunda sorun yaşamaları olumsuz yönleri olarak görülmektedir.

\section{Dunn-Dunn Öğrenme Stili Modeli}

Rita Dunn ve Kenneth Dunn (1979) tarafından geliştirilen bu modelde, Dunn (1999) öğrenme stilinin beşte üçünün kişiye biyolojik olarak doğuştan yüklendiğini ifade etmektedir. Ona göre öğrencilerin başarısızlık nedeni öğretim programları değildir, çünkü öğrenciler kendilerine ne öğre- 
tilirse öğretilsin öğrenecek kapasitedelerdir. Yeter ki konular onların öğrenme stillerine cevap veren ve uygun olan yöntem ve yaklaşımlarla öğretilsin. Dunn ve Dunn; öğrenme stillerinin bireyin a) çevresel, b) duygusal, c) sosyolojik (sosyal), d) fiziksel ve e) psikolojik (uyarıcılar) olmak üzere beş alandaki tercihlerine dayalı olduğunu ileri sürmektedir. Bireylerin bu her kategorideki ihtiyaç ya da tercihleri, onun öğrenme stili demektir (Arslangilay, 2015). Dunn ve Dunn modelinin belirlediği, uyarıc1lara yönelik tercihlere göre stiller ve bu stilleri bilen bir öğretmenin sinıf ortamında ve öğretim sürecinde neler yapabileceğine dair öneriler şu şekilde sunulabilir (Dunn ve Griggs, 1998; Ailen vd., 2010; Akt: Arslangilay, 2015; Koç Erdamar, 2015):

Çevresel uyarıcılar (ses, 1şık, sıcaklık, sınıf düzeni): Öğrenmenin olması için seçilen ses, 1şık, 1sı durumları ve düzeni ile ilgili koşullardır. Öğrencilerin bunlarla ilgili tercihleri farklılık gösterir. Öğrencilerin ses konusundaki tercihleri düşünülürse, bazı öğrenciler çok sessiz ortamlar tercih ederken bazıları da müzik dinlemeyi ya da daha gürültülü ortamları tercih eder. Öğretmen sessiz çalışmayı tercih eden öğrencilerine bireysel çalışmalar, sesli çalışmayı tercih eden öğrenciler için de tartışma etkinlikleri ya da müzik dinleme etkinlikleri sunabilir. Öğrencilerin 1şık konusundaki tercihleri yine birbirlerinden farklı olmaktadır. Bazı öğrenciler aydınlık bir ortamda daha rahat çalışırken bazıları da daha loş bir ışık tercih edebilirler. Sıcaklık da öğrencilerin öğrenme süreçlerini önemli derecede etkileyen çevresel uyarıcılardan biridir. Bu biyolojik reaksiyon ile bazı öğrenciler daha sıcak ortamları bazıları da daha serin ortamları tercih etmektedirler.

Psikolojik uyarıcılar (global-analitik, yansıtan-tepkisel): Bazı öğrenciler bir şeyi öğrenirken önce tüm bilgiyi görmeyi, bazıları da parçalardan yola çıkarak tüm bilgiye ulaşmayı, bazıları bütünsel, bazıları da ayrıntılara odaklanarak öğrenmeyi tercih ederler. Bazı öğrenciler sonuca ulaşmak için olabildiğince hızlı düşünmeyi tercih ederken bazıları da var olan seçenekleri değerlendirerek bir sonuca ulaşmayı tercih ederler. Öğretmenler bütüncül öğrencilerine tüm resmi görmelerini sağlayacak analitik öğrencileri için de ayrıntılarla öğrenmelerini sağlayacak etkinlikler sunabilir. 
Beyin fırtınası ve tartışma gibi yöntemler hızlı düşünen öğrenciler, problem çözme ve bireysel çalışmalar gibi etkinlikler de seçenekleri değerlendirip hızlı bir karar vermeyi tercih etmeyen öğrenciler için uygun olabilir.

Sosyolojik uyarıcılar (yalnız çalışmak, ikili çalışmak, grup halinde çalışmak, bir otorite figürüyle çalışmak, çeşitlilik değişken): Öğrencilerin nasıl bir sosyal ortamda öğrenmek istemeleriyle ilgilidir. Her öğrencinin çal1şırken yalnız kalmak, arkadaşlarıyla çalışmak ya da ne yapması gerektiğini kendine söyleyecek bir öğretmen gibi otorite figürü isteme gibi farklı tercihleri vardır. Öğretmen yapacağı yazılı sınavların dışında yalnız çalışmayı tercih eden öğrencilere bireysel, grupla çalı̧̧mayı tercih eden öğrencilere grup çalışmaları ve tartışmalar yaptırabilirken otoriteye ihtiyaç duyarak öğrenen öğrencileri için de düzenli bir şekilde dönüt sağlamalı ve açılamalar yapmalıdır.

Duygusal uyarıcılar (motivasyon, süreklilik, sorumluluk, yapılandırma, sebat): Öğrencinin öğrenmeye güdülenmesi, çalışmada süreklilik (sebat), öğrenme sorumluluğu ve öğrenmede yapılanmışlı gibi özelliklerle ilgilidir. Öğrencilerin bazıları öğrenmeye diğerlerine göre daha fazla ilgi duyarken bazıları daha az güdülenmiştir. Sorumluluk duygusu daha fazla geliştiği için öğrenmesi ile ilgili tüm görev ve sorumluluklarını en iyi şekilde yerine getirmeye çalışan öğrenciler kadar yapacakları işlere karşı daha az sorumluluk hisseden öğrenciler de vardır. Düzenli çalışmayı tercih eden öğrenciler olduğu gibi, arada bir çalışmayı tercih eden öğrenciler de vardır. Öğrenecekleri şeyin tek bir cevabı olmasını isteyen öğrenciler gibi, açık uçlu ve çok seçenekli etkinliklerden daha iyi öğrenen öğrenciler de vardır. Öğretmen, kendisini güdüleyebilen öğrencilerine "öz-düzenleyici öğrenme ve değerlendirme stratejileri," diğer öğrencileri için de "dışsal güdüleme stratejileri" kullanabilir. Kendisi zaten sorumluluk sahibi olan ve kararlılıkla çalışan öğrencilere çok fazla rehberlik yapması gerekmeyen öğretmen bu öğrencilerine daha uzun süren görevler verebilir. Ancak daha az sorumluluk sahibi ve daha az azimli öğrencilerine takip edebileceği kısa süreli görevler vermeli ve mutlaka dönüt sağlamalıdır. Yapılandırılmamış öğrenme etkinliklerini tercih eden öğrencilerine problem çözme çalışmaları, açı uçlu sorular gibi etkinlikleri daha az yönerge ile verebilecek öğretmen; yapılandırılmış etkinlikleri tercih eden öğrencileri 
için daha fazla açıklama ve yönerge sunmalı ve onları takip edebilecekleri aşamalı etkinliklere yönlendirmelidir.

Fizyolojik uyarıcılar (algı, yeme-içme, zaman, hareketlilik): Öğrencilerin öğrenme için duyu organı ve zaman dilimi seçme, öğrenme sırasında yeme ve hareket etme ihtiyacı duyup duymama ile ilgili özelliklerdir. Öğrencilerin bazıları görsel, bazıları işitsel, bazıları da kinestetik algılayarak öğrenirler. Okul çağındaki öğrencilerin yaklaşık \%20-30’u işitsel öğrenirken; yani duydukları şeyleri öğrenen ve hatırlayan kişilerken, yaklaşık \%40'1 görsel, geriye kalan \%30-40'1 da dokunsal, görsel ya da her üçünün de birleşimidir. Öğretimin \%90'a yakınının ders anlatma ya da ders anlatma ve tartışmaya dayalı olması ne deniyle de pek çok öğrenci istenilen başarıyı yakalayamamaktadır. Bir diğer nokta, ders çalışırken ya da bir şeylere yoğunlaşırken yeme, içme, sakız çiğneme, sigara içme gibi ihtiyaçların insanların nasıl öğrendiğinin bir parçası olmasıdır. Yine kişinin enerjisinin ne zaman daha yüksek olduğu da (sabah ya da gece saatleri gibi) öğrenme için önemli bir faktördür. Öğrenmeye imkân sağlayan ya da engelleyen bir diğer faktör kişinin belirli bir süre boyunca sabit kalabilmesidir. Belirli zaman aralıklarıyla hareket etme ihtiyacı duyan pek çok çocuğa hiperaktif denmesi de bu yüzdendir. Hareket etme ihtiyacı duyan öğrencileri için öğretmen bu öğrencilerin sınıf içerisinde kısa süreli sık aralar vermelerine izin verebilir ya da sınıf içerisinde hareket etmesini sağlayacak etkinlik yaptırabilir. Öğretmen, ders çalışırken, öğrenirken yeme içme ihtiyacı duyan öğrenciler için sabah ile öğle yemeği arasında atıştırma saati verebilir; ders aralarında atıştırmalarını ya da sırayla her bir öğrencinin sınıfa atıştırmalık bir şeyler getirmesini isteyebilir. Daha fazla yoğunlaşma gerektiren dersleri günün daha erken saatlerine alan ve daha hareket gerektiren etkinlikleri de öğleden sonraya planlayan bir öğretmen "zaman" konusunda öğrencilerine yardımcı olur.

\section{Felder \& Silverman'nın Öğrenme Stili Modeli}

Felder ve Silverman öğrenme stillerini, duyusal ve sezgisel, görsel ve işitsel, tümevarımla ve tümdengelimle, aktif ve yansıtıcı, ardışık ve bütünsel olarak beş boyutta gruplandırmıştır (Felder ve Silvernian, 1988; Felder, 1996; Akt: Kayacık, 2013; Veznedaroğlu ve Özgür, 2005; Yetim, 2008). 
Duygusal ve sezgisel öğrenenler: Duygusal öğrenenler somutturlar, pratiktirler, gerçeklere ve işlemlere yöneliktirler. Duygusallar genellikle iyi temellendirilmiş yöntemlerle problemleri çözmekten hoşlanırlar, karışıklik ve sürprizlerden hoşlanmazlar. Duygusallar, detaylar konusunda iyidirler. Duygusallar, sezgisellere göre daha pratik ve dikkatli olma eğilimindedirler, gerçekleri ezberlemede iyidirler. Duygusallar gerçek dünya ile bağlantısı açı ve net bir şekilde belli olmayan derslerden hoşlanmazlar. Sezgisel öğrenenler kavramsaldırlar, yenilikçidirler, teori ve anlam yönelimlidirler. Genellikle olasılıkları ve ilişkileri keşfetmeyi tercih ederler, tekrarlardan hoşlanmazlar. Yeni kavramları algılamada ve anlamada iyidirler ve genellikle soyutlamalar ve matematiksel formülleri kullanmada duygusallara göre daha iyidirler. Sezgiseller duygusallara göre daha hızlı çalışma ve değişiklik ve yenilik yaratma konusunda iyidirler. Sezgiseller çok fazla ezber ve rutin hesaplamaların olduğu derslerden hoşlanmazlar. Herkes bazen duygusal ve bazen sezgisel olabilir.

Görsel ve sözel (işitsel) öğrenenler: Görsel öğrenenler, resimler, diyagramlar, basılı materyaller gibi görsel sunumları tercih ederler. Sözel öğrenenler, yazılı ve sözlü açıklamaları tercih ederler. Herkes, bilgiyi hem görsel hem de sözel olarak sunulduğunda daha iyi bir şekilde öğrenir.

Aktif ve yansıtıcı öğrenenler: Aktif öğrenenler, deneyerek ve diğerleriyle birlikte çalışarak öğrenirler. Yani bir şeyi, aktif bir şekilde yaptıklarında (onu, diğer kişilere açıkladıklarında, konuyu diğerleriyle tartıştıklarında ve konu üzerinde doğrudan uygulama yaptıklarında) anlarlar ve hatırda tutarlar. Aktif öğrenenlerin, kullandıkları ifade, "Hadi onu deneyelim ve nasıl çalıştığını görelim" şeklindedir. Grupla çalışma eğilimindedirler. Herhangi bir fiziksek etkinlik ve faaliyetlerde bulunmadıkları ve yalnızca not tutarak oturdukları dersler onlar için sıkıcıdır ve zordur. Yansıtıcı öğrenenler, konular üzerinde düşünerek ve yalnız başlarına çalışarak öğrenirler. Yansıtıcı öğrenenlerin sıklıkla kullandıkları ifade, "Hadi onun üzerinde düşünelim" şeklindedir. Herkes, bazen aktif ve bazen de yansitıc1dir. 
Tümevarmla ve tümdengelimle öğrenenler: Tümevarımla öğrenenler ayrıntılardan genele ulaşırlar. Tümdengelimle öğrenenler ise önce geneli öğrenip, daha sonra ayrıntıya inerler.

Ardışık ve bütünsel öğrenenler: Ardışık öğrenenler problemin çözümüne ilerlerken doğrusal muhakemeyi tercih ederler, öğrendiklerinin doğrusal (aşamalı, sıralı) olmasını severler. Bütünsel öğrenenler bilgiyi yığın biçiminde bütünsel olarak alırlar ve ansızın ilişkileri keşfederler.

\section{Alan Bağımlı ve Alan Bağımsız Öğrenme Stili Modeli}

Alan bağımlı ve alan bağımsız öğrenme stilleri 1940'larda Herman Witkin tarafından ortaya atılmıştır. Özellikle 1970'li yıllarda alan bağımlı-alan bağımsız stiller üzerine yoğun çalışmalar olduğu dikkat çekmektedir (Peker, 2003b). Bazı araştırmacılar bütüne odaklanan öğrencileri tanımlamak için bütünsel/görsel terimlerini, tersi bir eğilim gösterenleri tanımlamak içinse sözel/analitik terimlerini kullanmışlardır. Öte yandan bazıları bütünsel/görsel öğrenme tarzı için alan duyarlı terimini, sözel/analitik öğrenme tarzı için de alan duyarsız terimini kullanmışlardır. Bu terimler temelde insanların dünyaya nasıl baktığıyla ilişkilidir. Alan bağımlı olan insanlar dünyayı büyük, bağlantılı yapılar şeklinde görme eğilimindedirler. Örneğin, bir volkana baktıklarında genel şeklini, ana renklerini ve topografik özelliklerini fark ederler. Öte yandan, alan bağımsız olanlar manzaraya yakından bakıp daha küçük parçaları fark ederler. Dolayısıyla, örneğin, tek tek ağaçları, farklı kayaları, kalderin büyüklüğünü, kalderin yapının neresinde olduğunu, lav akış boyutunu gösteren topografik özellikleri vb. fark edebilirler. Tablo 5 'te alan bağımlı ve alan bağımsız öğrencilerin özellikleri ve öğretim stratejileri yer almaktadır. 
Tablo 5. Alan Bă̆ımlı ve Alan Bağımsız Öğrencilerin Özellikleri ve Öğretim Stratejileri

\begin{tabular}{|c|c|}
\hline \multicolumn{2}{|l|}{ Özellikleri } \\
\hline Alan Bağımlı (Duyarlı) Öğrenciler & Alan Bağımsız Öğrenciler \\
\hline İşbirliği yapmayı sever. & Rekabeti sever. \\
\hline Öğretmenden rehberlik ister. & Öğretmenden nadiren rehberlik bekler. \\
\hline Kavramların bütünsel yanlarını görür. & Kavramların detaylarına odaklanır. \\
\hline $\begin{array}{l}\text { Müfredat kişiselleştirir - kavramları kişisel } \\
\text { deneyimine bağlar. }\end{array}$ & Gerçeklere ve ilkelere odaklanır. \\
\hline $\begin{array}{l}\text { Örgütlemenin öğretmen tarafından yapılma- } \\
\text { sını tercih eder. }\end{array}$ & Bilgiyi kendi başına örgütleyebilir. \\
\hline $\begin{array}{l}\text { Birlikte çalışmayı sever ve onların duygu ve } \\
\text { düşüncesine duyarlıdır. }\end{array}$ & Yalnız çalışmayı tercih eder. \\
\hline $\begin{array}{l}\text { Öğretmenle ilişkilerini güçlendirecek ödüller } \\
\text { kazanmaya çalışır. }\end{array}$ & $\begin{array}{l}\text { Öğretmenle resmi etkileşimleri sınıftaki gö- } \\
\text { revleri ile sinırlıdır -sosyal olmayan ödülleri } \\
\text { tercih eder. }\end{array}$ \\
\hline \multicolumn{2}{|l|}{ Öğretim Stratejileri } \\
\hline $\begin{array}{l}\text { Onayınızı ve sıcaklığınızı fiziksel ve sözel } \\
\text { olarak gösterin. }\end{array}$ & $\begin{array}{l}\text { Etkileşimlerinizi dolaysız kurun, konu hâki- } \\
\text { miyetinizi gösterin. }\end{array}$ \\
\hline Sosyal ve somut ödüllerle güdüleyin. & $\begin{array}{l}\text { Not gibi sosyal olmayan ödülleri kullanarak } \\
\text { güdüleyin. }\end{array}$ \\
\hline İşbirlikli öğrenme stratejileri kullanın. & $\begin{array}{l}\text { Tam öğrenme ve yanlışsız öğretim stratejile- } \\
\text { rini kullanın. }\end{array}$ \\
\hline Sık sık düzeltici geri bildirimler verin. & Gerekli olduğunda geri bildirim verin. \\
\hline Öğrenmede etkileşime müsaade edin. & Bağımsız projelere müsaade edin. \\
\hline Dersleri, projeleri ve ödevleri yapılandırın. & $\begin{array}{l}\text { Öğrencilerin kendi yapılarını oluşturmala- } \\
\text { rına imkân verin. }\end{array}$ \\
\hline $\begin{array}{l}\text { Sunucu gösterici, kontrol edici, pekiştirici, } \\
\text { not verici ve materyal geliştirici rollerini üst- } \\
\text { lenin. }\end{array}$ & $\begin{array}{l}\text { Danışman, dinleyen, anlaşmacı ya da kolay- } \\
\text { laştırıcı rollerini üstlenin. }\end{array}$ \\
\hline
\end{tabular}

Kaynak: Franklin,1992; Mshelia, 2008; Tharp, 1989; Sprenger, 2008'den uyarlayan Aydın, 2014.

\section{Gregorc Öğrenme Stili Modeli}

Gregorc'a göre bireyin öğrenmesinde ve öğrenme stilinin oluşmasında algılama yeteneği oldukça önemlidir. Bireyler algılama yetenekleri açısından somut ve soyut algılayanlar olarak ikiye ayrılırlar. Algıladıkları verileri düzenleme yeteneklerine göre ise ardışık ve random (dağınık) olmak üzere iki gruba bölünürler. Bireylerin algılama yeteneklerine göre oluşturdukları öğrenme durumları onların öğrenme stillerini oluşturmaktadır. Bu modelde soyut random, somut random, soyut ardışık, somut ard1- 
şık adı altında dört öğrenme stili yer almaktadır (Ekici, 2002). Bu dört öğrenme stiline sahip bireylerin taşıdıkları özellikler şu şekilde açılanabilir (Gregorc, 1979;1984; Gregorc ve Ward, 1977; Akt: Ekici, 2002):

Somut ardışık (doğrusal) öğrenme stiline sahip bireylerin özellikleri: Yaparak yaşayarak öğrenmeyi sever, bilgilerin adım adım ve basitten karmaşığa doğru verilmesini isterler. Yaptıkları çalışmaların parçalarından çok bütünü önem verir, öğrenmek için çok ve zaman harcar, işlerini zamanında ve düzenli bitirmek isterler. Beş duyu organı gelişmiş olan bu öğrenme stiline sahip öğrenciler somut materyallere dokunmayı, onlarla ilgilenmeyi severler. Plastikten, alçıdan, vb. modeller veya simülatörler onlar için fazla bir anlam ifade etmemektedir. Talimatları beklemekle kalmazlar ayn zamanda ilgili talimatlara uyarak, temiz düzenli ve kurallara uyarak çalışmayı tercih ederler. Gregorc' ye göre bireylerin yaklaşık \%27'si bu öğrenme stiline sahiptir.

Soyut ardışık (doğrusal) öğrenme stiline sahip bireylerin özellikleri: $\mathrm{Bu}$ öğrenme stiline sahip bireyler, ilk olarak öğrenecekleri konuyla ilgili zihinlerinde boş bir harita veya resim gibi bir çerçeve yapı oluştururlar. Bu adımı takiben konuyla ilgili kendilerine düzenli olarak sunulan bilgilerden uygun olanları belirli bir düzen içerisinde alır ve daha önce zihinlerinde oluşturdukları harita resim çerçevesinin içerisine yerleştirerek konunun bütünü hakkında bir sonuca varmaya çaba gösterirler. Bu kişiler oldukça gelişmiş bir şifre çözme yeteneklerine sahiptir. Dolaysıyla bazen bir şekil veya sembol yüzlerce kelimeden değerli olabilir. Bu grupta yer alan bireyle fikirlere ve kavramlara önem verir, kavramları mantıksal olarak düzenlerler. Yazılı bir kaynaktan veya kitaptan öğrenmeyi, yeni kavramlar ve fikirler üretmeyi, kavramlarla uğraşmayı severler. Bilgileri bir otoriteden veya tecrübeli bir kişiden öğrenmeyi tercih etmektedirler. Gregorc, somut ve soyut öğrenme stiline sahip bireylerin oranın aynı yani yaklaşık \%27 olduğunu vurgulamaktadır.

Somut random (dağını) öğrenme stiline sahip bireylerin özellikleri: Problem çözme konusunda üstün yetenekleri olan bu öğrenme stiline sahip bireyler gerçek problemlerle ilgilenmek isterler. Problemle ilgili yeni bilgi ve kavrama ulaşmaya çalışan araştırmacı bir yapıları vardır. Sebepleri 
araştırmadan hoşlanır ve beklenmedik durumlar dikkatlerinin çeker. Problem çözme sürecinde bilgilerin sistematik düzen içerisinde sunulmasına ihtiyaç duymaz ve önceden belirlenmiş işlem basamaklarını sevmezler. Dolayısıyla bu tip öğrenenlerin çalışmalarına öğretmenin doğrudan müdahale etmesi uygun değildir. Bağımsız veya küçük gruplarla çalışmayı sevmektedirler. Bireylerin yaklaşık \%19'u bu öğrenme stili içerinde yer almaktadir.

Soyut random (dağınık) öğrenme stiline sahip bireylerin özellikleri: $\mathrm{Bu}$ öğrenme stiline sahip bireyle olayları ve kavramları karışık şekilde alg1larlar. Çünkü onlar için öğrenilecek bilgilerde belirli bir düzenin olmasına ihtiyaç yoktur. Bu nedenle çoklu duyumsal deneyimlerin bulunduğu ortamlarda öğrenmeyi tercih etmektedirler. Düşünce ve duygularını açıkça ifade etmekte yeterli ve başarılıdırlar. Düzen ve kuralcılığı sevmedikleri için elde ettikleri verileri istedikleri gibi organize etmeyi tercih ederler. $\mathrm{Bu}$ öğrenme stiline sahip bireylerin oranı da yaklaşık \%27'dir.

\section{Canfield Öğrenme Stili Modeli}

Canfield'e (1988) göre, bireysel öğrenme stili; akademik koşullar (diğer öğrenciler ve eğitmenlerle olan ilişkiler), yapısal koşullar (organizasyon ve detaylar), başarı koşulları (hedef belirleme ve rekabet), içerik (sayılar, sözcükler, vb.), tercih edilen öğrenme şekli (dinleme, okuma, dolaylı ve doğrudan yaşantı) ve işi gerçekleştirme beklentisinden (üstün başarıdan yeterli düzeyine kadar) oluşmaktadır. Canfield, tanımladığ lerinde Willing ve Kolb'un tanımladığı öğrenme stillerine benzer olarak alana bağımlı ve alandan bağımsız olma özellikleri ile pasiflik ve aktiflik kişilik özelliklerinin kombinasyonları temele almıştır. Canfield'in çalışmaları sonucunda alana kazandırdığı dokuz öğrenme stilinin genel özellikleri aşağıda yer almaktadır (Bolat, 2007):

Sosyal öğrenme stili: Küçük veya grup çalışmalarını seven, öğretmenler ve diğer öğrencilerle etkileşimi ve işbirliğini tercih eden, kavramsal ve uygulamalı yaklaşımlardan hoşlanmayan öğrencilerin sahip olduğu öğrenme stilidir. 
Bă̆ımsız öğrenme stili: Bireysel hedeflerine ulaşmada yalnız çalışmayı ve örnek olay çalışmaları gibi kendi seçtiği öğretim yöntemlerini tercih eden, kavramsal ve uygulamalı yaklaşımlardan uzak duran öğrencilerin sahip olduğu bir öğrenme stilidir.

Uygulamalı öğrenme stili: Laboratuvar çalışmaları ve çevre gezileri gibi hayatla doğrudan ilintili etkinlikleri seven, bağımsız ve sosyal yaklaşımları tercih etmeyen öğrencilerin sahip olduğu bir öğrenme stilidir.

Kavramsal öğrenme stili: Düzenlenmiş sözel materyallerle çalışmaya istekli, okuma ve düz anlatım yöntemlerini kullanan, bağımsız ve sosyal yaklaşımları önceleyen öğrencilerin sahip olduğu öğrenme stilidir.

Sosyal/uygulamalı öğrenme stili: Grupla problem çözme, rol oynama, işbirlikli öğrenme gibi yöntemleri kullanan, diğer öğrenciler ve öğretmenlerle etkileşim sürecinde olan ve yaşamla doğrudan ilintili etkinlik ve aktivitelerde yer almayı seven öğrencilerin sahip olduğu bir öğrenme stilidir.

Sosyal/kavramsal öğrenme stili: Öğretmenlerle ve diğer öğrenciler etkileşim sürecinde düzenlenmiş sözel materyallerin, anlatım ve tartışma yöntemlerinin ağırlıklı olduğu bir öğretim sürecini isteyen öğrencilerin sahip olduğu öğrenme stilidir.

Bă̆ımsız/uygulamalı öğrenme stili: Doğrudan hayatla ilintili öğrenme yaşantılarında yer alırken, bireysel hedeflerine varmada yalnız çalışmayı seven, rehbersiz teknik çalışmalar ve laboratuvarda bireysel çalışma gibi öğrenme teknikleri tercih eden öğrencilerin sahip olduğu bir öğrenme stilidir.

Băğımsı/kavramsal öğrenme stili: Bireysel hedeflerini gerçekleştirirken organize edilmiş sözel materyallerin ağırlıklı olduğu öğrenme-öğretme sürecinde yalnız çalışmayı seven, bağımsız okuma ve edebiyat çalışmalarını tercih eden öğrencilerin sahip olduğu stildir. 
Nötr öğrenme stili: Bazı zaman ve durumlarda dikkatini toplamada zorluk yaşayan ve güçlü tercihleri bulunmayan öğrencilerin sahip olduğu öğrenme stilidir.

\section{Sonuç}

Her birey sahip olduğu nitelikler bakımından birbirinden farklıdır. Öğrenme stilleri, bireysel farklılıkların en önemlileri arasında yer almaktadır. Sınıf içerisinde yer alan öğrencilerin bireysel farklılıkları dışında öğrenilen konu, öğrenme-öğretim yöntem ve teknikleri, teknolojik araç-gereçler, öğretmen, okul, sınıf vb. tüm dış koşullar her öğrenci için benzer veya aynıdır. Ancak aynı olan bu dış koşullar altında öğrenim hayatını sürdüren öğrencilerin öğrenme veya akademik başarı düzeyleri birbirine yakın olmayabilir. Burke ve Dunn (2003), her öğrencinin birbirlerinden farklı şekilde öğreneceğinden, aynı öğretim ortamı, yöntemi, tekniği ve kaynakların bazı öğrenciler için etkili bazı öğrenciler için ise daha az etkili olduğunu vurgulamaktadır. Bu nedenle eğim sürecinde öğrencilerin öğrenme stillerini göz önünde bulundurarak öğretim yapılması bireylerin öğrenme ortamında psikolojik, bilişsel vb. yönlerden daha rahat olmalarını, daha kolay ve kalıcı öğrenmelerini sağlayabilir. Bireysel farklılıkların içerisinde önemli bir boyut olan öğrenme stilleri bu durumun tek etkeni olmasa da bu farklılığın en önemli bileşenlerinden birisi olduğunu söylemek mümkündür. Öğrenme sürecinde bu kadar önemli bir işleve sahip olan öğrenme stili, bir bireyi diğer bireylerden ayıran parmak izi veya kan grubu kadar önemlidir. Yani, bireylerin öğrenme stilleri birbirlerinden farklılık sergilemektedir. Bu durum öğrenme sürecinde öğrenme stillerinin dikkate alınması gerektiğini göstermektedir. Bu bağlamda Ekici'ye (2003) göre öğrenme stillerine dayalı öğretimin yararları şu şekilde açıklanabilir:

- Öğrenciler öğrenmeye istekli olurlar.

- Yaratıcı öğrenme ürünleri ortaya çıkabilir.

- Sınıf yönetiminde öğretmenlere yardımcı olur.

- Öğretmenin rehberlik görevi artar ve kolaylaşır.

- Sınıf içi düzeni bozan öğrenci davranışları azalır.

- Özdenetim geliştirmelerinde öğrencilere yardımcı olur.

- Bireylerin yeteneklerinin farkına varmasına katkı sağlar.

- Öğrencinin sorumluluk alma ve karar verme yetenekleri gelişir. 
- Öğretmen, öğrenen ve üstün yetenekli öğrencilere çok zaman ayırır.

- Farklı öğretim-öğrenme model ve yöntem kullanımına yardımcı olur.

- Öğrenciler öğrenme süreçlerinden, başarı/başarısızlık durumlarından sorumlu oldukları için öğretim faaliyetlerini de değerlendirebilir.

- Öğrenci-öğretmen, öğrenci-öğrenci ilişkilerinde, sınıf içi kararların alınmasında, düşüncelerin ifade edilmesinde vb. demokratik bir sınıf atmosferi oluşmasına katkı sağlar.

Nitekim, konuyla ilgili yapılan araştırma sonuçları öğrencilerin birbirlerinden farklı yollarla öğrendiklerini, bilgiyi alma ve işleme konusunda farklı bireysel tercihlerinin bulunduğunu ve başta akademik başarı olmak üzere öğrenme stilleriyle çeşitli değişkenler arasında pozitif bir ilişki olduğunu somut olarak ortaya koymaktadır (Arslan ve Durukan, 2015; Ataseven ve Oğuz, 2015; Aydemir, Koçoğlu ve Karalı, 2016; Biçer ve Durukan, 2014; Çelik ve Gündüz, 2016; Demir ve Aybek, 2012; Demir, 2008; Dikmen, Tuncer ve Şimşek, 2018; Dilmaç, Ertekin ve Yazıcı, 2009; Doğru, 2017; Durukan, 2013; Emir ve Kaplan Sayı, 2013; Erden, 2017; Erdoğan ve Güzel, 2013; Karamustafaoğlu vd., 2016; Koç Akran, 2018; Oral, 2003; Sidekli ve Akdoğdu, 2018; Süral ve Sarıtaş, 2015; Varışoğlu, 2018; Yenice ve Saracaloğlu, 2009; Yücelsin Taş ve Erdem, 2015).

Reinert (1976)'a göre bireylerin öğrenme stilleri belirlenmeden veya öğrenilmeden eğitim-öğretim sürecinde bireysel farklılıkların dikkate alınmasından söz edilemez. Dolayısıyla öğrenme stillerini belirleme araçları uygulanarak öğrencilerin öğrenme stilleri belirlenmeli ve öğrenme süreci bu öğrenme stillerine uygun olarak düzenlenmelidir. Bu konuda, yeterli sayıda olmasa da ülkemizde öğrenenlerin öğrenme stillerinin belirlenmesi için envanter (ölçek, anket, form vb.) geliştirmeye yönelik araştırmalar yapılmış ve çeşitli envanterler geliştirilmiştir (Aşkar ve Akkoyunlu, 1993; Cesur ve Fer, 2011; Dağhan ve Akkoyunlu, 2011; Ekici, 2002;2006; Otrar, 2008; Akgün vd., 2014; Polat ve Güven, 2017; Sarıtaş ve Süral, 2010; Yeşilyurt, 2014).

Sonuç olarak, alanyazın taraması sonucunda erişilen kaynaklarda (kitaplar, tezler, makaleler, bildiriler) öğrenme stillerinin tamamının bir bütünlük içerisinde ve kapsamlı olarak açıklamasına ulaşılamamıştır. Öte yandan öğrenenlerin öğrenme stilini belirlemek amacıyla kullanılacak (hazırlanmış, geliştirilmiş) ölçme envanterlerinin (ölçek, anket, form vb.) yeterli olduğunu belirtmek güçtür. Derleme niteliği taşıyan bu çalışma 
kapsamında alanyazında en fazla yer alan öğrenme stili modelleri ayrıntılı bir şekilde ele alınmış ve açıklanmıştır. Alanyazında farklı kaynaklarda yer alan öğrenme stillerinin bir bütünlük içerisinde ve tek çalışma kapsamında toplanması ve ele alınması çalışmanın özgünlügü ortaya koymaktadır. Bir bakıma öğrenme stilleri el kitapçığı gibi olan bu çalışmanın alana katkı sağlayacağı umulmaktadır. 


\title{
EXTENDED ABSTRACT
}

\section{Learning Style Models: A Comprehensive Review in the Context of Theoretical Basics \\ *}

\author{
Etem Yeşilyurt \\ Akdeniz University
}

The transition from teacher-centered education to student-centered education is among the changes that affect education systems. This change makes the individual differences of the learners more important, including learning styles. Research on individual differences between learners has led to the introduction of "learning style" in the literature. Concepts related to learning styles began to appear in the early 1890s. However, important studies on learning styles started to be carried out in the late 1950s and early 1970s. The concept of learning style used by Frank Riessman in the 1960s with the term "learning style was first used by Rita Dunn in 1960 and research on this issue began to increase in number and quality after 1980s.

In general terms, style is a link between talent and personality; the preference of the individual to use his / her abilities is the way he / she prefers to use his / her knowledge and skills. Learning style can be defined as the way in which a student is born, his / her own way of learning, remembering or using the information, the situation that shows how he / she learns and likes to learn, trends or preferences in the learning process and conditions.

General characteristics of learning styles can be summarized as follows.

- There are many ways to teach and learn.

- The learning style is not necessarily immutable.

- Learning and teaching styles should be compatible.

- Learning style and learning strategy are different concepts.

- Biological origin is more dominant in an individual's learning style.

- The use of individual differences in the learning environment is a wealth. 
- Knowing the learning style increases the academic achievement of the student.

- Knowing the learning style affects the choice of teaching methods and techniques.

- Each individual may have different and / or multiple styles in terms of learning style

Many variables are intertwined with or influence learning styles. Each learning style has biological, sociological, environmental, personal, cognitive, affective, physiological and other properties were more effective than others in the emergence of different learning style models. There are points where learning style models overlap. However, while some learning style models are based on all of the behavioral characteristics such as cognitive, affective and psychic, some of them are limited to one dimension such as cognitive or psychological.There are learning stye models in the literature developed by Jung, Myers-Briggs, Lawrance, Fleming \& Mill, Reinert, Kolb, Honey and Mumford, 4MAT, Grasha-Riechmann, Dunn-Dunn, Felder-Silverman, Field dependent and independent, Gregorc, Canfield, Curry, Barsch, Brandt, Butler, Hermann, Hill, Kagan, Keirsey-Bates, Letteri, Merril, NASSP, Riding-Cheema, Silver-Hanson, Simon-Byram, Torrance and Witkin. The most well known in the scope of this study are as follows;

- Jung's theory of psychological types

- Myers-Briggs Type Indicator Model

- Lawrence learning style model

- Fleming \& Mill's learning style model

- Reinert's learning style model

- Kolb's learning style model

- Honey \& Mumford's learning style model

- 4MAT learning style model

- Grasha-Riechmann's learning style model

- Dunn-Dunn's learning style model

- Felder-Silverman's learning style model

- Field dependent and independent learning style model

- Gregorc's learning style model

- Canfield's learning style model 
Each individual is different from each other in terms of qualifications. Learning styles are among the most important of individual differences. Apart from the differences of the individuals in the classroom, the subject, learning-teaching methods and techniques, technological tools, teacher, school, classroom etc. all external conditions are similar or the same for each student. However, under these same external conditions, the level of learning or academic achievement of students who continue their education is not the same or very close. Because the same teaching environment, method, technique and resources are effective for some students, they may be less effective for some students. For this reason, teaching in the educational process by taking into consideration the learning styles of the students may let them feel more comfortable and easier and more permanent in terms of psychological, cognitive and etc. in learning environment. Although learning styles, which are an important dimension of individual differences, are not the only factors, it is one of the most important components of this difference. Learning style, which has such an important function in the learning process, is as important as the fingerprint or blood type that separates an individual from other individuals. In other words, learning styles of individuals differ from each other. This shows that learning styles should be taken into consideration in the learning process.

As a matter of fact, the results of the research reveal that the students have learned in different ways from each other, that they have different individual preferences in receiving and processing information, and that the positive relationship between learning styles and various variables, especially in academic achievement, is concrete.

As a result of literature review, it is not possible to provide a comprehensive explanation of all learning styles in the sources (books, theses, articles, papers). On the other hand, it is difficult to state that the measurement inventories (scale, questionnaire, form, etc.) to be used (prepared, developed) to determine the learning style of the learners are sufficient. Within the scope of this compilation study, the most common learning style models in the literature are discussed and explained in detail. Collecting and addressing the learning styles in different sources in a single study within the context of a single study reveals the originality of the study. It is hoped that this study, which is like a handbook of learning styles, will contribute to the field. 


\section{Kaynakça / References}

Abidin, M. J. Z., Rezaee, A. A., Abdullah, H. N. and Singh, K. K. B. S. (2011). Learning styles and overall academic achievement in a specific educational system. International Journal of Humanities and Social Science, 1(10), 143-152.

Akdeniz, C. (2007). Öğrenme stili modelleri, 02.08.2019 tarihinde https://docplayer.biz.tr/ 18900373-Ogrenme-stili-modelleri-celal-akdeniz-sunu-raporu-epo-614-ogretme-ve-ogrenme-stratejileri-yrd-doc-dr-meral-guven-eskisehir.html adresinden erişilmiştir.

Akgün, Ö. E., Küçük, Ş., Çukurbaşı, B. veTonbuloğlu, İ. (2014). Sözel veya görsel baskın öğrenme stilini belirleme ölçeği Türkçe formunun geçerlik ve güvenirlik çalışması. Bartın Üniversitesi Eğitim Fakültesi Dergisi, 3(1), 277-297.

Akkoyunlu, B. (1995). Bilgi teknolojilerinin okullarda kullanımı ve öğretmenlerin rolü. H.Ü. Eğitim Fakültesi Dergisi, 11, 105-109.

Arslan, N. ve Durukan, E. (2015).Ortaokul öğrencilerinin öğrenme stilleri ve yazma eğilimleri arasındaki ilişki. Uluslararası Türkçe Edebiyat Kültür Eğitim Dergisi, 4(3), 1251-1267.

Arslangilay, A. S. (2015). Öğretim ilke ve yöntemleri. (Ed. S. Güven ve M. A. Özerbaş), Öğrenme ve öğretim stilleri içinde (s. 59-113), Ankara: Pegem Akademi.

Aşkar, P. ve Akkoyunlu, B. (1993). Kolb öğrenme stili envanteri. Eğitim ve Bilim, 17(87), 37-47.

Ataseven, N. ve Oğuz, A. (2015). Türkiye'de öğrenme stilleri konusunda yapılan tezlerin incelenmesi. Ĕ̆gitim ve Öğgretim Araştırmaları Dergisi, 4(3), 192-205.

Aydemir, H., Koçoğlu, E. ve Karalı, Y. (2016). Grasha-Reichmann ölçeğine göre öğretmen adaylarının öğrenme stillerinin değerlendirilmesi, Kastamonu Ĕ̆itim Dergisi, 24(4), 1881-1896.

Aydın, H. (2014). Etkili öğretim yöntemleri: Araştırma temelli uygulama (Çev. Ed. B. Acat), Öğrencilerinizi anlamak içinde (s. 36-66), Ankara: Nobel Akademik Yayıncllık.

Babadoğan, C. (1994). Öğrenme stilleri ve stratejileri arasındaki ilişki, 1. Eğitim Bilimleri Kongresi: Kuram-Uygulama-Araştırma, Cilt 3, (1056-1065), 2830 Nisan 1994, Adana: Ç.Ü. Eğitim Fakültesi. 
Bahar, M. (2009). Öğrencilerin öğrenme stilleri ve mini fen proje çalışmalarındaki performansları arasındaki ilişki. Kuram ve Uygulamada Eğitim Bilimleri, 9(1), 7-52.

Biçer, M. (2010). İlköğretim 6., 7., 8. sınf öğrencilerinin sinı düzeyleri, cinsiyetleri, akademik başarıları ve ders grupları ile öğrenme stilleri arasında ilişki, Yüksek Lisans Tezi, Yıldız Teknik Üniversitesi, İstanbul.

Biçer, N. ve Durukan, E. (2014). Ortaokul öğrencilerinin öğrenme stilleri ile okumaya yönelik tutumları arasındaki ilişki. Millî Eğitim, 204, 199213.

Bilgin, İ. ve Bahar, M. (2008). Sınıf öğretmenlerinin öğretme ve öğrenme stilleri arasındaki ilişkinin incelenmesi. Gazi Eğitim Fakültesi Dergisi, 28(1), 19-38.

Bolat, N. K. (2007). Ilköğretim 6. ve 7. sinıf fen ve teknoloji bilgisi dersi öğrencilerinin öğrenme stillerine göre motivasyon ve başarı düzeyleri, Yüksek Lisans Tezi, Osmangazi Üniversitesi, Eskişehir.

Boydak, H. A. (2001). Öğrenme stilleri. İstanbul: Beyaz Yayınları.

Burke, K. ve Dunn, R. (2003). Learning style-based teaching to raise minority student test scores: There is no debate!. The Social Studies, 94(4), 167170.

Cesur, M. O. ve Fer, S. (2011). Dil öğrenme stratejileri, stilleri ve yabancı dilde okuma anlama başarısı arasındaki ilişkileri açıklayıcı bir model. H.Ü. Eğitim Fakültesi Dergisi, 41, 83-93.

Çelik, H. Ç. ve Gündüz, S. (2016). İlköğretim matematik öğretmen adaylarının akademik başarı ve matematiğe yönelik tutumlarını öğrenme stilleri açısından incelenmesi, Z.G. Ĕ̆gitim Fakültesi Dergisi, 28, 278-288.

Dağhan, G. ve Akkoyunlu, B. (2011). Maggie Mcvay lynch öğrenme stili envanterinin Türkçeye uyarlanma çalışması. H.Ü. Eğitim Fakültesi Dergisi, 40, 117-126.

Demir, R. ve Aybek, B. (2012). Dokuzuncu sınıf öğrencilerinin öğrenme stilleri ve çoklu zekâ alanlarının incelenmesi. Uluslararası Eğitim Programları ve Öğretim Çalışmaları Dergisi, 2(4), 27-40.

Demir, T. (2008). Türkçe eğitimi bölümü öğrencelerinin öğrenme stilleri ve bunların çeşitli değişkenlerle ilişkisi:Gazi Üniversitesi örneği Uluslararası Sosyal Araştırmalar Dergisi, 1(4), 129-148.

Demirel, Ö. (2012). Kuramdan uygulamaya eğitimde program geliştirme. Ankara: Pegem A Yayıncilik. 
Demirkaya, H. (2003). Coğrafya öğretiminde 4MAT öğretim sisteminin lise coğrafya derslerindeki başarı ve tutumlar üzerine etkisi. Doktora Tezi, Gazi Üniversitesi, Ankara.

Demirkaya, H., Mutlu, M. ve Uşak, M. (2003). 4MAT öğretim sistem modeli'nin çevre eğitimine uygulanması. Pamukkale Üniversitesi Eğitim Fakültesi, Dergisi, 2(14), 68-82.

Dikmen, M., Tuncer, M. ve Şimşek, M. (2018). Öğrenme stilleri ile öğrenmeye yönelik tutum arasındaki ilişki. Uluslararası Sosyal Araştırmalar Dergisi, 11(57), 388-400.

Dilmaç, B., Ertekin, E. ve Yazıcı, E. (2009). Değer Tercihleri ve öğrenme stilleri arasındaki ilişkinin incelenmesi. Değerler Eğitimi Dergisi, 7(17), 27-47.

Doğru, S. (2017). Matematik öğretiminde, öğrenme stilleri ve önkoşul öğrenmelere dayalı etkinliklerin etkisi. Mediterranean Journal of Humanities, 2(7), 189-209.

Dunn, R. S. ve Dunn, K. J. (1979). Learning styles/teaching styles: Should they ... can they ... be matehed? Educational Leadership, 36(4), 238-244.

Durukan, E. (2013). Türkçe öğretmen adaylarının öğrenme stilleri ve öğrenme stratejileri arasındaki ilişki. Turkish Studies, 8(1), 1307-1319.

Ekici, G. (2002). Gregorc öğrenme stili ölçeği. Eğitim ve Bilim, 27(123), 42-47.

Ekici, G. (2003). Öğrenme stiline dayal öğretim ve biyoloji dersi öğretimine yönelik ders plan örnekleri, Ankara: Gazi Kitabevi.

Ekici, G. (2006). Hanson Silver öğrenme tercihi envanteri'nin geçerliği ve güvenirliğine ilişkin bir çalışma. Ĕ̆itim ve Bilim Dergisi, 31(140), 10-17.

Emir, S. ve Kaplan-Sayı, A. (2013). Öğrenme stillerinin duygusal zekâ üzerine etkisinin incelenmesi. Kastamonu Eğitim Dergisi, 21(2), 791-804.

Erden, M. ve Altun, S. (2006). Öğrenme stilleri. İstanbul: Morpa Kültür Yayınları.

Erden, N. S. (2017). Yeni nesillere yeni öğretim yöntemleri: Z kuşağının öğrenme stilleri ve yükseköğrenim için öneriler. International Journal of Academic Value Studies, 3(12), 249-257.

Erdoğan, Ş. ve Güzel, H. (2013). Fizik derslerindeki başarılı ve başarısız öğrencileri öğrenme ve düşünme stillerinin karşılaştırılması. OPUS-Türkiye Sosyal Politika ve Çalışma Hayatı Araştırmaları Dergisi, 3(5), 31-48.

Ergür, D. O. (1998). Hacettepe Üniversitesi dört yillık lisans programlarındaki öğrenci ve öğretim üyelerinin öğrenme stillerinin karşılaştırllması. Doktora Tezi, Hacettepe Üniversitesi, Ankara. 
Evin-Gencel, İ. (2006). Öğrenme stilleri, deneyimsel öğrenme kuramına dayalı e $\breve{g} i-$ tim ve sosyal bilgiler program hedeflerine erişi düzeyi. Doktora Tezi, Dokuz Eylül Üniversitesi, İzmir.

Evin-Gencel, İ. (2007). Kolb’un deneyimsel öğrenme kuramına dayalı öğrenme stilleri envanterini Türkçeye uyarlama çalışması. Dokuz Eylül Üniversitesi Sosyal Bilimler Enstitüsü Dergisi, 9(2), 120-139.

Fer, S. (2005). Aday öğretmenlerin düşünme stilleri nedir? XIV. Ulusal Eğitim Bilimleri Kongresi Bildiri Özet Kitabı, 28-30, Eylül 2005, Denizli.

Grasha, A. F. (1996). Teaching with style: A practical guide to enhancing learning by understanding teaching and learning, Pittsburg, PA: Alliance.

Gregorc, A. F. (1979). Learning/teaching styles: Potent forces behind them. Educational Leadership, 36(4), 234-236.

Gregorc, A. F. (1984). Style as a symptom: A phenomenological perspective. Theory Into Practice, 23(1), 51-56.

Gündoğan Çögenli, A. (2011). Sınıföğretmenlerinin sahip oldukları öğrenme stilleri ve kullandıkları bilişüstü öğrenme stratejileri, Yüksek Lisans Tezi, Anadolu Üniversitesi, Eskişehir.

Güneş, G. ve Gökçek, T. (2012). Pedagojik formasyon öğrencilerinin öğrenme stilleri. Ĕ̆gitim ve Öğretim Araştırmaları Dergisi, 1(4), 28-40.

Güven, B. (2008). İlköğretim öğrencilerinin öğrenme stilleri, tutumları ve akademik başarıları arasındaki ilişkinin incelenmesi. Türkiye Sosyal Araştırmalar Dergisi, 12(1), 35-54.

Güven, M. (2004). Öğrenme stilleri ile öğrenme stratejileri arasındaki ilişki. Doktora Tezi, Anadolu Üniversitesi, Eskişehir.

Karademir, E. ve Tezel, Ö. (2010). Sınıf öğretmeni adaylarının öğrenme stillerinin demografik değişkenler açısından incelenmesi. Pamukkale Üniversitesi Ĕ̆itim Fakültesi Dergisi, 28(2), 129-145.

Karakuyu, Y. ve Tortop, H. S. (2010). Öğretmen adaylarının öğrenme stillerinin fizik dersine yönelik tutum ve başarılarına etkisi. Afyon Kocatepe Üniversitesi Fen ve Mühendislik Bilimleri Dergisi, 10(1), 47-55.

Karamustafaoğlu, O., Şeker, Ş., Şahin, H. ve Denizli, Z. (2016). Ortaokul öğrencilerinin öğrenme stillerinin farklı değişkenlerle incelenmesi. Gazi Ĕ̆itim Bilimleri Dergisi, 2(1), 51-68.

Kayacık, E. (2013). Öğrencilerin Kolb öğrenme stillerine göre çalışma alışkanlıkları, ödev yapma motivasyonları ve stilleri üzerine bir çalışma. Yüksek Lisans Tezi, Osmangazi Üniversitesi, Eskişehir. 
Kılıç, E. (2002). Web Temelli Öğrenmede baskın öğrenme stilinin öğrenme etkinlikleri tercihi ve akademik başarıya etkisi, Yüksek Lisans Tezi, Ankara Üniversitesi, Ankara.

Koç-Erdamar, G. (2015). Öğretim ilke ve yöntemleri (Ed. Y. Budak), Öğrenme stratejileri ve ögrrenme stilleri içinde (s. 285-326), Ankara: Pegem Akademi.

Koç-Akran, S. (2018). 5. ve 6. sınıf öğrencilerinin öğrenme stilleri ile akademik başarıları arasındaki ilişki:Malatya ve Elazı̆̆ ili örneği. Curr Res Educ, $4(2), 62-85$.

Kolb, D. (1984). Experiential learning: Experience as the source of learning and development, New Jersey: Prentice Hall.

Köse, A. (2010). Fen bilgisi öğretmen adaylarının öğrenme stilleri, ders çalışma stratejileri ile fen bilgisi öğretimi öz yeterlik inançları arasındaki ilişki ÇOMü Örneği. Yüksek Lisans Tezi, Onsekiz Mart Üniversitesi, Çanakkale.

Kumar, P., Kumar, A. ve Smart, K. (2004). Assessing the impact of instructional methods and information technology on student learning styles. Issues in Informing Science and Information Technology, 1, 533-544.

More, A. J. (1987). Native Indian learning styles: A review for researchers and teachers. Journal of American Indian Education, 27(1), 17-29.

Myers, I. B. ve Myers, P. B. (1997). Kişilik "farklı tipler farklı yetenekler" (Çev. H. Ovacık), Kuraldışı Yayınları: İstanbul.

Oral, B. (2003).Ortaöğretim öğrencilerinin öğrenme stillerinin incelenmesi, Kuram ve Uygulamada Ĕ̆itim Yönetimi Dergisi, 35, 418-435.

Otrar, M. (2008). Marmara öğrenme stilleri ölçeğinin (ÖSÖ-M) geçerlik ve güvenirlik çalışması. Kuram ve Uygulamada Ĕ̆itim Bilimleri, 3(7), 14021419.

Özer, B. (1998). Eğitim bilimlerinde yenilikler. (Ed. H. Ayhan), Öğrenmeyi öğretme (s.146-164), Anadolu Üniversitesi Açıöğretim Fakültesi Yayınlar1.

Peker, M. (2003a). Kolb öğrenme stili modeli. Milli Ĕ̆gitim Dergisi, 01.07.2019 tarihinde http://dhgm.meb.gov.tr/yayimlar/dergiler/Milli EğitimDergisi/157/peker.htm adresinden erişilmiştir.

Peker, M. (2003b). Öğrenme stilleri ve 4 MAT yönteminin öğrencilerin matematik tutum ve başarılarına etkisi. Doktora Tezi, Gazi Üniversitesi, Ankara.

Peker, M., Mirasyedioğlu, Ş. ve Yalın, H. İ. (2003). Öğrenme stillerine dayalı öğretimde 4 MAT öğretim modeli. Pamukkale Üniversitesi Ĕ̆itim Fakültesi Dergisi, 1(13), 1-14. 
Polat, M. ve Güven, M. (2017). Edmonds öğrenme stilleri belirleme ölçeğinin Türkçeye uyarlama çalışması. Ilköğretim Online, 16(2), 848-859.

Reinert, H. (1976). One picture is worth a thousand words: Not necessarily. The Modern Language Journal, 60(4), 160-168.

Riding, R. ve Rayner, S. (1998) Cognitive styles and learning strategies: Understanding style differences in learning and behaviour, London: D. Fulton Publishers.

Sarıtaş, E. ve Süral, S. (2010). Grasha-Reichmann öğrenme ve öğretme stili ölçeklerinin Türkçe uyarlama çalışması. e-Journal of New World Sciences Academy Education Sciences, 5(4), 2162-2177.

Sever, E. (2008). Öğrenme stilleri: İlköğretim 6-8. sinıföğrencilerine yönelik bir ölçek geliştirme çalışması. Yüksek Lisans Tezi, Adnan Menderes Üniversitesi, Aydin.

Sidekli, S. ve Akdoğdu, E. (2018). Öğrenme stillerinin sınıf öğretmeni adaylarının akademik başarılarını yordama gücü. H.Ü. Ĕgitim Fakültesi Dergisi, 33(2), 503-517.

Sünbül, A. M. (2011). Öğretim ilke ve yöntemleri. Konya: Eğitim Kitabevi Yayınları.

Süral, S. ve Sarıtaş, E. (2015). Sınıf öğretmenliği öğretmen adaylarının fen ve teknoloji öğretimi dersindeki öğrenme stilleri ile akademik başarıları arasındaki ilişki, Recep Tayyip Erdoğan Üniversitesi Sosyal Bilimler Dergisi, 1(1), 31-44.

Taşpınar, M. (2012). Kuramdan uygulamaya öğretim ilke ve yöntemleri. Ankara: Elhan Kitap Yayın Dağ.

Turan, H., Şahin, İ. ve Altın, E. N. (2018). Ortaöğretim öğrencilerinin kişilik özellikleri ve boş zaman değerlendirme tercihlerinin değerlendirilmesi. Turkish Studies Educational Sciences, 13(19), 1807-1820.

Ural-Alşan, E. (2009). Kimya öğretmen adaylarının akademik başarılarına öğrenme stili tercihleri, öz kontrollü öğrenme ve motivasyon faktörlerinin etkisi. Doktora Tezi, Hacettepe Üniversitesi, Ankara.

Usta, A., Bodur, H., Yağız, D. ve Sünbül, A. M. (2011). İlköğretim fen bilgisi derslerinde öğrenme stillerine dayalı öğretim etkinliklerinin öğrenci erişi ve tutumlara etkisi. Ahmet Keleşoğlu Ĕ̆itim Fakültesi Dergisi, (31), 1-13.

Varışoğlu, M. C. (2018). Türk dili ve edebiyatı öğretmeni adaylarının öğrenme stilleri: Gaziosmanpaşa Üniversitesi örneği. Ekev Akademi Dergisi, 22(73), 573-584. 
Veznedaroğlu, R. L. ve Özgür, A. O. (2005) Öğrenme stilleri: Tanımlamalar, modeller ve işlevleri, İlköğretim-Online, 4(2), 1-6.

Yavuzalp, N. ve Gürol, M. (2017). E-öğrenme ortamında kullanılan öğrenme stillerinin web kullanım madenciliği ile analizi. A.İ.B.Ü. Ĕ̆itim Fakültesi Dergisi, 17(2), 987-1015.

Yazıcı, E. ve Sulak, H. (2008). Öğrenme stilleri ile ilköğretim beşinci sınıf matematik dersindeki başarı arasındaki ilişki. Ahmet Keleşoğlu Eğitim Fakültesi Dergisi, 25, 217-236.

Yenice, N. ve Saracaloğlu, A. S. (2009). Sınıf öğretmeni adaylarının öğrenme stilleri ile fen başarıları arasındaki ilişki. YYÜ Eğitim Fakültesi Dergisi, 6(1), 162-173.

Yeşilyurt, E. (2014). Öğretmen adaylarının öğrenme stillerinin belirlenmesi ve öğrenme stilleri arasındaki ilişkinin değerlendirilmesi. Ĕ̆itimde Kuram ve Uygulama, 10(4), 999-1021.

Yetim, H. (2008). Öğretim ilke ve yöntemleri (Ed. Ş. Tan), Öğrenme stilleri içinde (s. 181-219), Ankara: Pegem Akademi Yayınları.

Yıldız, G. (2010). İlköğretim 7. sınıf öğrencilerinin matematik başarıları, bilişüstü stratejileri, düşünme stilleri ve matematik öz kavramlar arasındaki ilişkiler. Doktora Tezi, Yıldız Teknik Üniversitesi, İstanbul.

Yücelsin Taş, Y. T. ve Erdem, E. (2015). Fransizca öğrenen öğrencilerin öğrenme stilleri üzerine bir araştırma. Synergies Turquie, 6, 151-161.

\section{Kaynakça Bilgisi / Citation Information}

Yeşilyurt, E. (2019). Öğrenme stili modelleri: Teorik temelleri bağlamında kapsayıcı bir derleme çalışması. OPUS-Uluslararası Toplum Araştırmaları Dergisi, 14(20), 2169-2226. DOI: 10.26466/opus.603506 